Title no. 90-S65

\author{
A report of research sponsored by \\ the Reinforced Concrete Research Council
}

\title{
Effect of Deformation Height and Spacing on Bond Strength of Reinforcing Bars
}

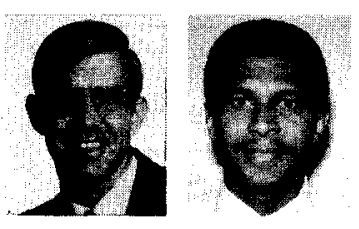

by David Danwin and Ebenezer K. Graham
The effect of deformation pattern on bond strength is studied using 1 in. $(25 \mathrm{~mm})$ diameter machined bars with deformation heights of $0.05,0.075$, and $0.10 \mathrm{in} .(1.27,1.91$, and $2.54 \mathrm{~mm})$ and deformation spacings ranging from 0.26 to $2.2 \mathrm{in.}(6.7$ to $56 \mathrm{~mm})$. The combinations of rib height and spacing produce relative rib areas (ratio of projected rib area normal to bar axis to product of nominal bar perimeter and center-to-center rib spacing) of 0.20, 0.10, and 0.05 for each deformation height. Conventional reinforcing bars, with a relative rib area of 0.07 , are also studied. The effect of deformation pattern is evaluated using beam-end specimens with varying degrees of confinement provided to the test bars. Degrees of confinement are: 1) 2-in. (5I-mm) cover without transverse stirrups, 2) 2-in. (51-mm) cover with confining transverse stirrups, and 3) 3-in. (76- $\mathrm{mm}$ ) cover without confining transverse stirrups. Bars with 2-in. $(51-\mathrm{mm})$ cover have an initial unbonded length of $1 / 2 \mathrm{in} .(13 \mathrm{~mm})$ and a bonded length of $12 \mathrm{in} .(305 \mathrm{~mm})$. Bars with 3-in. (76-mm) cover have an initial unbonded length of 4 in. (102 $\mathrm{mm})$ and $a$ bonded length of $8 \frac{1}{2} \mathrm{in}$. $(216 \mathrm{~mm})$.

The bond force-slip response of reinforcing bars is a function of the relative rib area of the bars, independent of the specific combination of rib height and rib spacing. Under all conditions of bar confinement, the initial stiffness of load-slip curves increases with an increase in the relative rib area. Under conditions of relatively low confinement, in which bond strength is governed by splitting of the concrete, bond strength is independent of deformation pattern. Under conditions in which additional bar confinement is provided by transverse reinforcement or higher cover, bond strength increases compared to the bond strength of bars with less confinement. The magnitude of the increase in bond strength increases with an increase in the relative rib area.

Keywords: bond (concrete to reinforcement); deformed reinforcement; pullout tests; reinforcing steels; structural engineering.

s.

There is widely conflicting evidence on the effect of deformation pattern on the bond strength between reinforcing bars and concrete. Some studies indicate that deformation pattern has a strong influence on bond strength. Other studies show that deformation pattern has little influence, and it is not uncommon for bars with different patterns to produce nearly identical development and splice strengths. This paper describes research designed to determine both the effects of deformation height and spacing on bond strength and the conditions under which these effects are observed.

\section{BACKGROUND}

The current criteria for reinforcing bar deformation patterns in the United States are based on research carried out more than forty years ago by Arthur P. Clark (1946, 1949) at the National Bureau of Standards (now the National Institute of Standards and Technology). Based on Clark's study of reinforcing bar patterns, Tentative Specification ASTM A 305-47T was developed and later modified (ASTM A 305-49) to include a maximum average spacing of deformations, or ribs, equal to 70 percent of the nominal diameter of the bar and a minimum, height of deformations equal to 4 percent for bars with a nominal diameter of $1 / 2$ in. (13 mm) or smaller, 4.5 percent for bars with a nominal diameter of $5 / 8$ in. (16 $\mathrm{mm})$, and 5 percent for larger bars. These provisions constitute the major deformation requirements in use today (ASTM A 615-90, A 616-90, A 617-90, A 706-90).

Clark's work was based primarily on pullout tests, but included some beam tests. His evaluation of bar performance was based on bond behavior throughout the usable range of bond stress, rather than on bond strength. Clark averaged the bond stresses at loaded end slips of $0.0005,0.001,0.002$, $0.003,0.004,0.005,0.0075$, and 0.01 in. $(13,25,51,76$, $102,127,191$, and $254 \mu \mathrm{m}$ ) for each bar. He then averaged the values for top and bottom-cast bars to obtain a single representative bond stress for each deformation pattern. His

ACI Structural Journal, V. 90, No. 6, November-December 1993.

Received June 6, 1993, and reviewed under Institute publication policies. Copyright (C) 1993, American Concrete Institute. All rights reserved, including the making of copies unless permission is obtained from the copyright proprietors. Pertinent discussion will be published in the September-October 1994 ACI Structural Journal if received by May $1,1994$.

ACI Structural Journal / November-December 1993 
David Darwin, FACI, is the Deane E. Ackers Professor of Civil Engineering and Director of the Structural Engineering and Materials Laboratory at the University of Kansas. He is a past member of the Board of Direction and the Technical Activities Committee and is Past-President of the Kansas Chapter of ACl. Darwin is Chairman of the Publications Committee and the Concrete Research Council and is a member and past-chairman of $\mathrm{ACl}$ Committee 224, Cracking. He is also a member of ACI Committees 408, Bond and Development of Reinforcement, 446, Fracture Mechanics, and ACI-ASCE Committees 445, Shear and Torsion, and 447, Finite Element Analysis of Reinforced Concrete Structures.

ACI member Ebenezer K. Graham is a structural engineer with DuBois Consultants, Inc., Kansas City, Missouri. He holds a B.Sc. (Eng.) in Civil Engineering and a M.Phil. in Structures from the University of Science and Technology in Ghana, and an MSCE from the University of Kansas.

reports (Clark 1946, 1949) do not include the peak stresses obtained in the tests.

At the time Clark made his recommendations on rib spacing and height, he also recommended that the ratio of the shearing area (bar perimeter times distance between ribs) to the rib bearing area (projected rib area normal to the bar axis) be limited to a maximum of 10 , and if possible 5 or 6 . Today this criterion is usually described in terms of the inverse ratio, i.e., the ratio of the bearing area to the shearing area, which is known alternately as the "rib area," "related rib area," or "relative rib area" (DIN 1986; Soretz and Holzenbein 1979). Relative rib area $R_{r}$ will be used as the descriptive term in this report.

$$
R_{r}=\frac{\text { projected rib area normal to bar axis }}{\text { nominal bar perimeter } \times \text { center-to-center rib spacing }}
$$

Clark's recommendations then become a minimum relative rib area, $R_{r}$, of 0.10 , with desirable values of 0.20 or 0.17 . It is interesting to note that Clark's rib area recommendations were not included in ASTM A 305-49 and that current deformation patterns in the U.S. (ASTM A 615), Europe (DIN 1986, ISO 1990) and Japan (JIS 1975) do not provide the relatively high bearing areas recommended by Clark. Typical values of $R_{r}$ for bars manufactured in the U.S. range from 0.057 to 0.084 (Choi et al. 1990). In 1949, the best performing deformation patterns were not used as the industry standard largely because of a desire on the part of the reinforcing bar producers only to remove the weakest patterns, rather than establish the best possible anchorage to concrete.*

Since the time of Clark's efforts, a great deal has been learned about the bond performance of deformed reinforcing bars. It is generally agreed that the bond between reinforcing steel and concrete consists of a chemical adhesion, friction, and mechanical interlock. For regular deformed bars, the effect of the mechanical interaction has long been believed to be the major contributor to bond strength (Menzel 1939; Lutz et al. 1966, Lutz and Gergely 1967).

During the late 1950s and the $1960 \mathrm{~s}$, Rehm $(1957,1961)$, Lutz, Gergely, and Winter (1966), and Lutz and Gergely (1967) demonstrated that, as reinforcing steel moves with respect to concrete, one of two failure modes can occur. Either the concrete in front of the ribs gradually crushes, resulting in a "plow-through" or pullout-type failure, or the ribs and/or crushed concrete in front of the ribs act as wedges,

*Wildt, Roger, 1991. Personal communication at Annual Meeting of Reinforced Concrete Research Council, Skokie, Il. introducing tensile stresses perpendicular to the bar axis, which result in a splitting failure of the concrete. Rehm (1957, 1961) found that if the ratio of rib spacing to rib height is less than 7 and if the rib face angle (or rib flank inclination, as it is called in Europe) is greater than $40 \mathrm{deg}$, the concrete in front of the ribs undergoes gradual crushing, followed by a pullout failure. If the ribs have a spacing to height ratio greater than 10 , for a rib face angle greater than $40 \mathrm{deg}$, the concrete in front of the ribs first crushes and then forms wedges that induce tensile stresses that, in turn, cause transverse cracking and longitudinal splitting of the concrete. In general, the higher the confinement, the more likely a pullout failure. However, in most structural applications, a splitting failure is more common (Clark 1949; Menzel 1952; Chinn, Ferguson, and Thompson 1955; Ferguson and Thompson 1962, Losberg and Olsson 1979; Soretz and Holzenbein 1979; Johnston and Zia 1982, Treece and Jirsa 1989; and Choi et al. 1991, to list but a few).

Slip of a reinforcing bar with respect to the concrete has the effect of crushing the concrete in front of the ribs, producing a rib with an effective angle of 30 to $40 \mathrm{deg}$ (Lutz and Gergely 1967), which, rather than the steel itself, acts as the wedge. Work by Skorobogatov and Edwards (1979) on bars with face angles of 48.5 and $57.8 \mathrm{deg}$ supports these observations. Skorobogatov and Edwards concluded that, in the range tested, the face angle does not affect bond strength since the high rib face angle is flattened by the crushed concrete wedge that reduces the effective face angle to a smaller value.

Losberg and Olsson (1979), in a study of three deformation patterns commonly used in Sweden, came to the conclusion that traditional pullout tests, of the type used by Clark, are not useful for predicting the response of reinforcing bars in actual structures, because the state of stress around the bars in pullout specimens is considerably different from the state of stress in actual structures, largely due to the additional confinement provided in pullout tests. Losberg and Olsson found that the three deformation patterns produced considerably different bond strengths when they were evaluated using a pullout test. However, in tests where splitting governed, they found little difference for the three patterns, with the possible exception that bars with ribs that were oriented obliquely to the longitudinal axis caused greater splitting and thus provided a slightly lower strength than bars with ribs at a right angle to the bar. They also tested some specially machined bars, with different deformation spacings, and found that splitting strength was not sensitive to rib spacing. Their tests indicated that bond capacity actually decreased once ribs became closer than about two-thirds of the bar diameter.

Soretz and Holzenbein (1979) studied a number of bar parameters, including the height and spacing of ribs, the inclination of the ribs with respect to the bar axis, and the cross-sectional shape of the ribs along the longitudinal direction of the bar. In one portion of their study, keeping the rib-bearing area per unit length constant while changing the spacing and height of the ribs, they found little difference in behavior, up to a slip of $1 \mathrm{~mm}$. However, for slips greater than $1 \mathrm{~mm}$, the bar with the lowest rib height exhibited 20 percent lower strength than the other two patterns tested. 
They also observed that the bar with the highest ribs caused more splitting. They concluded, somewhat in opposition to the observations of Losberg and Olsson (1979), that the optimum geometry would be rib spacings of 0.3 bar diameter and rib heights of 0.03 bar diameter to give the best combination of increased bond strength and limited splitting.

A recent study by Kimura and Jirsa (1992) using pullout specimens supports many of the earlier observations, including an increase in bond strength with increasing relative rib area.

In addition to research specifically addressing the effect of deformation pattern, statistical studies covering a wide range of splice and development data have shown that bond strength increases with increasing cover, bar spacing, and confinement provided by transverse reinforcement (Orangun, Jirsa, and Breen 1975, 1977; Darwin et al. 1992a, 1992b). For members without transverse reinforcement, the relationship observed between bond strength and development/splice length, cover, bar spacing, and bar size shows relatively little scatter (Darwin et al. 1992a, 1992b) and appears to be independent of deformation pattern. In contrast, the relationship for members with transverse reinforcement exhibits large scatter (Orangun, Jirsa, and Breen 1975, 1977). That large scatter may be due to the need for a better characterization of bond strength, which may need to include the effect of the deformation pattern, a parameter that has not yet been incorporated in the statistical analyses.

\section{RESEARCH SIGNIFICANCE}

The work by Clark (1946, 1949), Losberg and Olsson (1979), and Soretz and Holzenbein (1979), and Kimura and Jirsa (1992) indicates that, at least under some conditions, an increase in relative rib area will increase bond strength. However, under other conditions, changes in relative rib area will have no effect (Losberg and Olsson 1979; Orangun, Jirsa, and Breen 1975, 1977; Darwin et al. 1992a, 1992b). There is little agreement on precise criteria for rib spacing and height.

This paper describes the first major experimental effort in a large-scale study to improve the development characteristics of reinforcing bars. The goal of this effort is to determine the effect of rib height, spacing, and relative rib area on bond strength, including the conditions under which changes in deformation pattern play a role. Full details are provided by Darwin and Graham (1993). The results reported here provide guidance for the design of a new series of reinforcing bar patterns that are being placed in production as part of the overall research program.

\section{EXPERIMENTAL PROGRAM}

The principal parameters in this study are rib height, rib spacing, relatite rib area, and degree of confinement provided by concrete and transverse reinforcing steel. The study was carried out using specially machined reinforcing bars, along with bars with standard deformation patterns for comparison. A portion of the tests (not reported here) were used to modify the test specimen and test system (Darwin and Graham 1993). Results obtained for the final 110 specimens in the study (Groups 5 through 9) are presented.

\section{Test specimens}

The beam-end test specimens illustrated in Fig. 1(a) and 1(b) were used for most of the tests. The specimens contain a 1-in. (25.4-mm) nominal diameter bottom-cast test bar with a 2-in. (51-mm) cover and 15-in. (381 mm) of concrete above the bar. The specimens contain four closed stirrups to provide shear strength. The stirrups are oriented parallel, rather than perpendicular, to the sides of the specimens to limit their effect on a splitting bond failure. As shown in Fig. 1(b), some specimens include four additional No. $3(9.5-\mathrm{mm})$ bar stirrups to determine the effects of confinement provided by transverse reinforcement. The test specimens also contain two No. 6(19-mm) bars, with $1 \frac{1}{2} 2$-in. (38-mm) bottom and side cover, to serve as auxiliary flexural reinforcement. The overall dimensions are $9 \times 18 \times 24$ in. $(229 \times 457 \times 610 \mathrm{~mm})$. The specimens contain three transverse No. 5 (16-mm) bars that are used to aid in fabrication and testing. Specimen configuration is altered for Group 9, which is used to evaluate the effect of additional concrete confinement. This is obtained by raising the test bar and the No. 6 bar flexural reinforcement by 1 in. $(25.4 \mathrm{~mm})$.

Test bars extended 22 in. $(560 \mathrm{~mm})$ out from the face of the specimens. Two polyvinyl chloride (PVC) pipes were used as bond breakers to control the bonded length of the bar and to avoid a localized cone-type failure of the concrete at the loaded end of the specimen. Bonded lengths of $81 / 2$ and 12 in. (216 and $305 \mathrm{~mm}$ ) were used in conjunction with lengths of bond breaking PVC pipe in front of the bars (lead lengths) of 4 and 0.5 in. (102 and $13 \mathrm{~mm}$ ), respectively. The 12 in. $/ 0.5$ in. $(305 \mathrm{~mm} / 13 \mathrm{~mm})$ combination was used for Groups 5-8. The $8 \frac{1}{2}$ in./4 in. combination was used in conjunction with increased cover for Group 9.

During the course of the study, concern was raised about the possibility that the ultimate bond forces were limited by the bond strength of the No. 6 bars. In Groups 7 and 8, the straight No. 6 bars were replaced by hooked No. 6 bars. The hooked bars had a $1 \frac{1}{2}$-in. (38-mm) cover, with the tails of the hooks terminating $1 \frac{1}{2}$ in. ( $38 \mathrm{~mm}$ ) from the upper surface of the test specimen. The addition of the hooks increased the bond strength of some bars but did not materially affect the maximum capacity that could be obtained from the test specimen. Straight No. 6 bars were used as auxiliary flexural reinforcement in the balance of the tests.

The test configurations are summarized in Table 1.

\section{Materials}

Reinforcing steel-The principal test bars were machined from 110 ksi yield strength ASTM A 311 (1990) cold-rolled steel. The minimum diameter of all bars was $1.0 \mathrm{in}$. (25.4 $\mathrm{mm})$. Three test specimens each of 9 different deformation patterns were fabricated. As illustrated in Fig. 2(a), three rib heights, 0.05 in., 0.075 in., and 0.10 in. $(1.27,1.91$, and 2.54 $\mathrm{mm}$ ), were used with spacings ranging from 0.263 to 2.20 in. $(6.7$ to $56 \mathrm{~mm})$ to produce relative rib areas, $R_{r}$ [Eq. (1)], of $0.20,0.10$, and 0.05 . The patterns were selected to produce all three values of relative rib area for each deformation height. A 60 deg face angle was used on the machined bars to insure concrete crushing in front of the ribs prior to failure. 

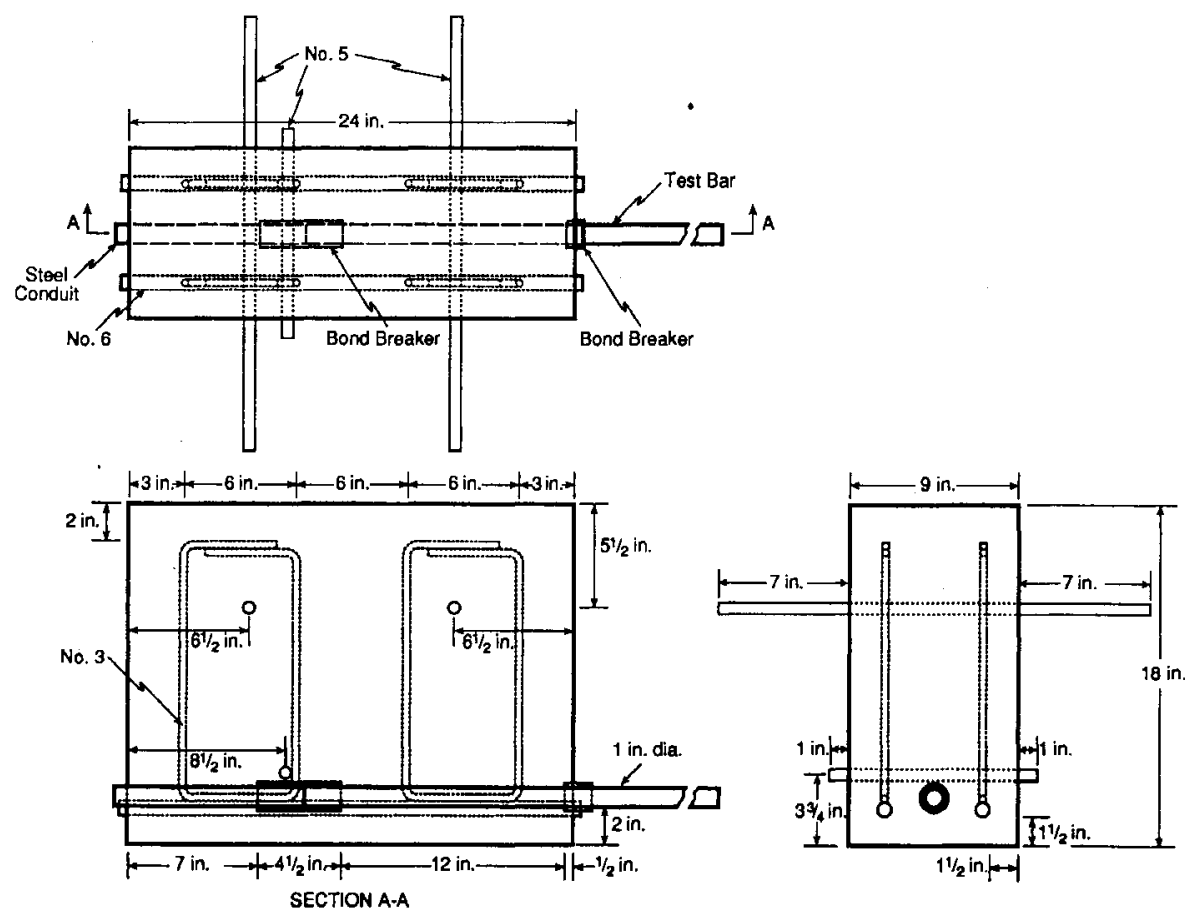

Fig. I(a)-Beam-end test specimen for evaluating the bond strength of reinforcing bars not confined by transverse reinforcement-Group 5. Modified as described in text for Groups 8 and 9 ( 1 in. $=25.4 \mathrm{~mm}$; bar size: No. $3=9.5 \mathrm{~mm} ;$ No. $5=16 \mathrm{~mm}$;o. $6=19$ $m m)$

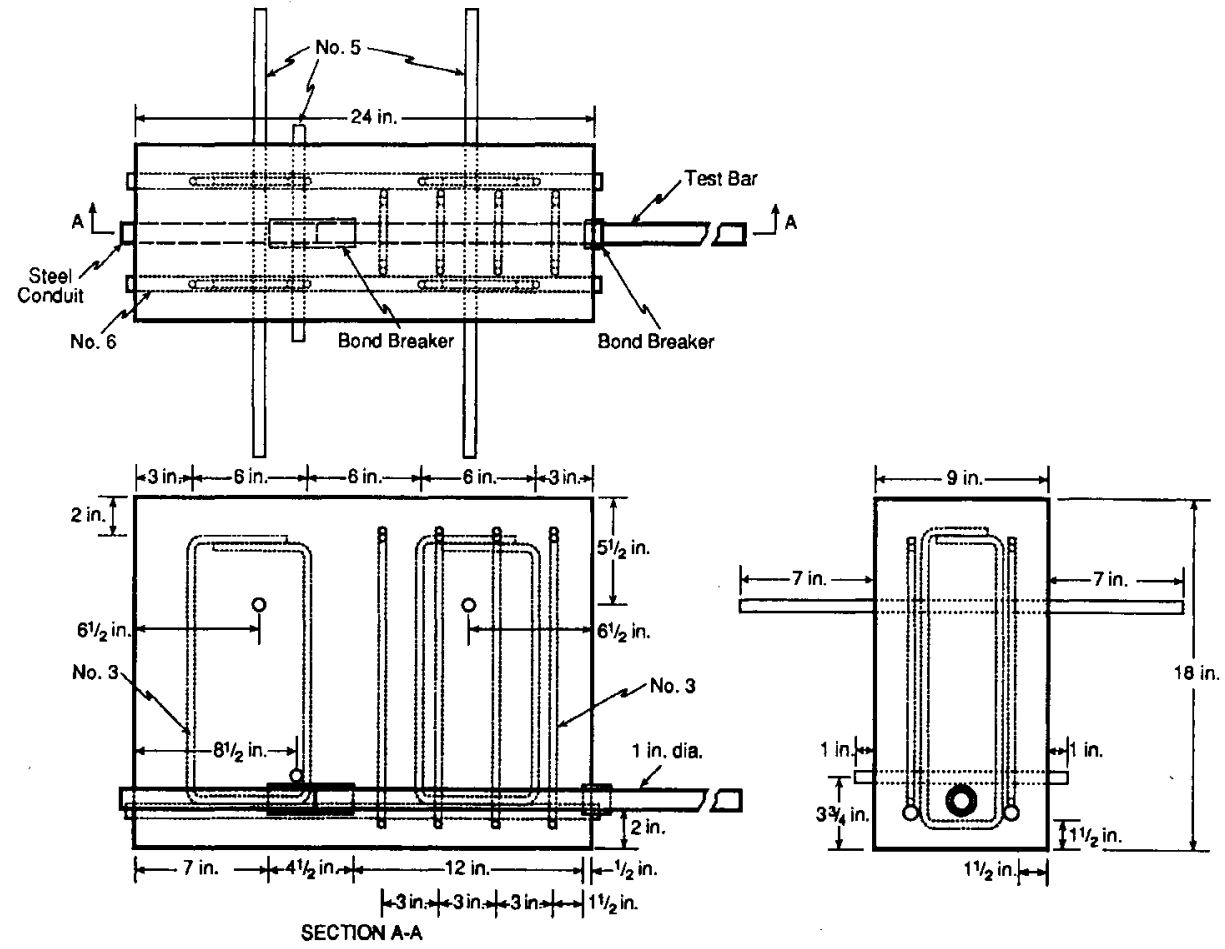

Fig. 1(b)-Beam-end test specimen for evaluating the bond strength of reinforcing bars confined by transverse reinforcement - Group 6. Modified as described in text for Group - 7 (1 in. $=25.4 \mathrm{~mm} ;$ bar size: No. $3=9.5 \mathrm{~mm} ;$ No. $5=16 \mathrm{~mm} ;$ No. $6=19 \mathrm{~mm}$ )

In addition to the machined bars, ASTM A 615 (1990) Grade 60 No. 8 (25.4 $\mathrm{mm}$ ) bars were evaluated to compare the prototype test bars to standard reinforcement. The pattern, designated $\mathrm{S}, R_{r}=0.07$, consisted of ribs perpendicular to the axis of the bar [Fig. 2(b)]. These bars were placed in the test specimens with longitudinal ribs oriented either vertically or horizontally. No. 3 bars, with ribs perpendicular to the axis of the bar, were used as stirrups. Reinforcing bar properties are summarized in Table 2.

Concrete-Air-entrained concrete was supplied by a local ready mix plant. Portland cement, 3/4-in. (19-mm) nominal maximum size crushed limestone, and river sand were used. 


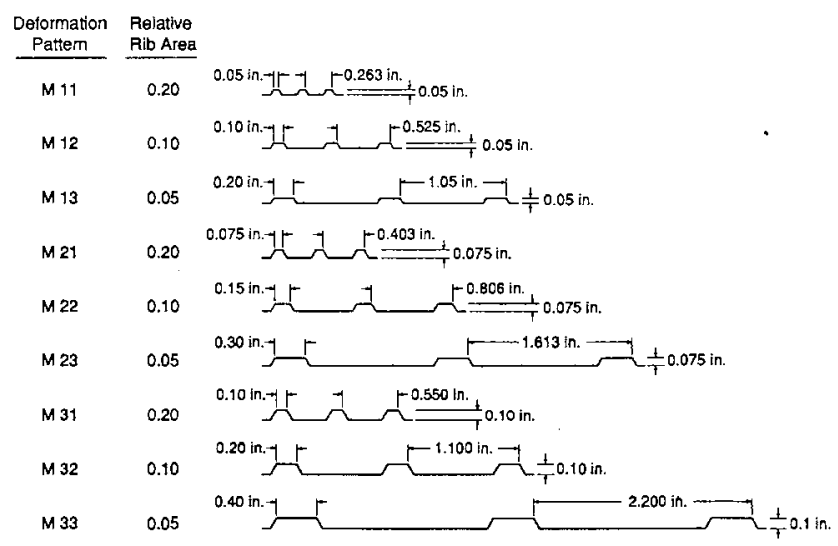

Fig. 2(a)-Machined bar deformation patterns. Face angle $=60 \mathrm{deg}$ for all bars $(1 \mathrm{in} .=25.4 \mathrm{~mm})$

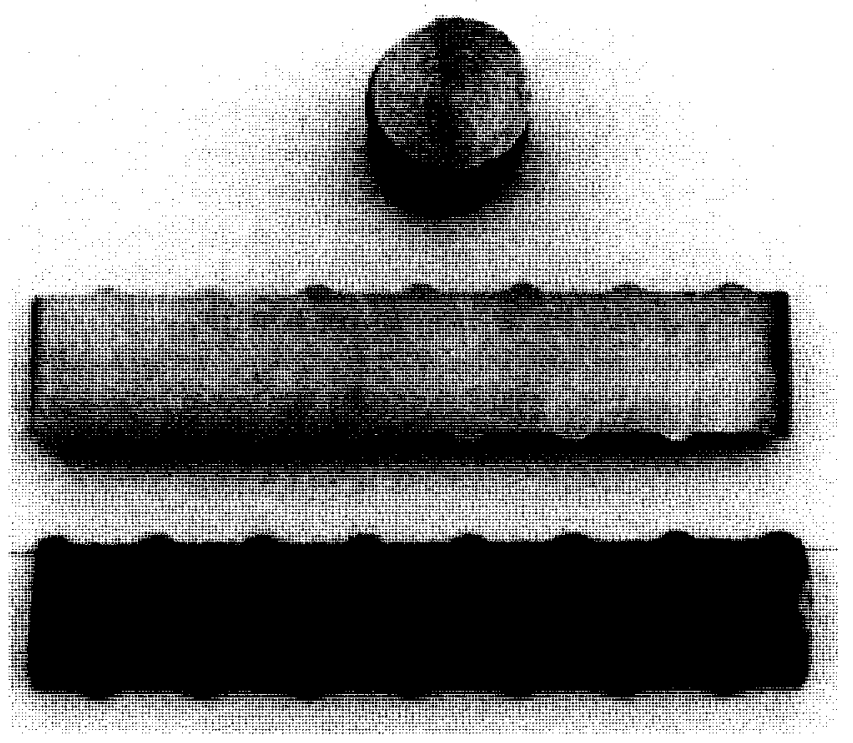

Fig. 2(b)-Conventional reinforcement deformation pattern

A water-cement ratio of 0.41 was used to produce strengths of 4500 to $6000 \mathrm{psi}$ ( 31 to $41 \mathrm{MPa}$ ) at the time of test. Mix proportions and concrete properties are given in Appendix A.*

\section{Test procedure}

The specimens were tested using an apparatus developed by Donahey and Darwin $(1983,1985)$, modified by Brettmann, Darwin, and Donahey $(1984,1986)$, and further modified in this study (Fig. 3). For Groups 5 through 8 , the reaction plate was positioned to bear on the bottom $3 \frac{1 / 2}{\mathrm{in}}$. $(89 \mathrm{~mm})$ of the test specimen, as illustrated in Fig. 3. This arrangement provided a lever arm of approximately $13 \% / 4$ in. ( $349 \mathrm{~mm}$ ) betwen the centroid of the compressive force and the test bar. For Group 9, the bearing plate was positioned to bear on the bottom $2 \frac{1}{2} 2$ in. $(64 \mathrm{~mm})$ of the test specimen providing a lever arm of approximately $13^{1} / 4$ in. $(337 \mathrm{~mm})$. Load was applied at a rate of about $6 \mathrm{kips}(27 \mathrm{kN})$ per minute.

\footnotetext{
*The appendixes are available in xerographic or similar form from $\mathrm{ACl}$ headquarters, where they will be kept permanently on file, at a charge equal to the cost of reproduction plus handling at time of request.
}

Table 1-Summary of test configurations

\begin{tabular}{c|c|c|c|c|c|c}
\hline & $\begin{array}{c}\text { Number } \\
\text { of speci- } \\
\text { mens }\end{array}$ & Cover, in. & $\begin{array}{c}\text { Trans- } \\
\text { verse } \\
\text { reinforce- } \\
\text { ment }\end{array}$ & $\begin{array}{c}\text { Banded } \\
\text { length, in. }\end{array}$ & $\begin{array}{c}\text { Lead } \\
\text { length, in. }\end{array}$ & $\begin{array}{c}\text { Auxil- } \\
\text { iary } \\
\text { flexural } \\
\text { reinforce- } \\
\text { ment }\end{array}$ \\
\hline 5 & 33 & 2 & no & 12 & 0.5 & straight \\
\hline 6 & 33 & 2 & yes & 12 & 0.5 & straight \\
\hline 7 & 11 & 2 & yes & 12 & 0.5 & straight \\
\hline 8 & 11 & 2 & no & 12 & 0.5 & hooked \\
\hline 9 & 22 & 3 & no & 8.5 & 4.0 & straight \\
\hline 1 in. $=25.4 \mathrm{~mm}$ & & & &
\end{tabular}

\section{Table 2-Reinforcing bar properties}

\begin{tabular}{c|c|c|c|c|c|c|c}
\hline $\begin{array}{c}\text { Nomi- } \\
\text { nal bar } \\
\text { diame- } \\
\text { ter, in. }\end{array}$ & $\begin{array}{c}\text { Defor- } \\
\text { mation } \\
\text { pattern }\end{array}$ & $\begin{array}{c}\text { Yield } \\
\text { strength, } \\
\text { ksi }\end{array}$ & $\begin{array}{c}\text { Defor- } \\
\text { mation } \\
\text { height, } \\
\text { in. }\end{array}$ & $\begin{array}{c}\text { Defor- } \\
\text { mation } \\
\text { spacing, } \\
\text { in. }\end{array}$ & $\begin{array}{c}\text { Deforma } \\
\text { tion } \\
\text { gap, in. }\end{array}$ & $\begin{array}{c}\text { Defor- } \\
\text { mation } \\
\text { angle, } \\
\text { deg }\end{array}$ & $\begin{array}{c}\text { Relative } \\
\text { rb area* }\end{array}$ \\
\hline $3 / 8$ & $\mathrm{~B}$ & 77.3 & 0.032 & $0.256^{\dagger}$ & $0.115^{\dagger}$ & 90 & $\ddagger$ \\
1 & $\mathrm{~S}$ & 71.1 & 0.055 & $0.667^{\dagger}$ & $0.175^{\dagger}$ & 90 & 0.07 \\
\hline 1 & $\mathrm{M} 11$ & 110 & 0.050 & 0.263 & - & 90 & 0.20 \\
1 & $\mathrm{M} 12$ & 110 & 0.050 & 0.525 & - & 90 & 0.10 \\
1 & $\mathrm{M} 13$ & 110 & 0.050 & 1.050 & - & 90 & 0.05 \\
\hline 1 & $\mathrm{M} 21$ & 110 & 0.075 & 0.403 & - & 90 & 0.20 \\
1 & $\mathrm{M} 22$ & 110 & 0.075 & 0.806 & - & 90 & 0.10 \\
1 & $\mathrm{M} 23$ & 110 & 0.075 & 1.613 & - & 90 & 0.05 \\
\hline 1 & $\mathrm{M} 31$ & 110 & 0.100 & 0.550 & - & 90 & 0.20 \\
1 & $\mathrm{M} 32$ & 110 & 0.100 & 1.100 & - & 90 & 0.10 \\
1 & $\mathrm{M} 33$ & 110 & 0.100 & 2.200 & - & 90 & 0.05 \\
\hline 1 & \\
\hline
\end{tabular}

Bar slip was measured using spring-loaded linear variable differential transformers (LVDTs). Two LVDTs were attached to the test bar with an aluminum yoke to measure loaded end slip. A single LVDT was placed in contact with the back end of the test bar through the steel conduit to measure unloaded end slip.

\section{RESULTS AND OBSERVATIONS}

The specimens in Groups 5, 8, and 9 [cover $=2,2$, and 3 in. $(51,51$, and $76 \mathrm{~mm})$, respectively] contained bars that were not confined by transverse reinforcement. The specimens in Groups 6 and 7 [cover $=2$ in. $(51 \mathrm{~mm})$ ] contained bars that were confined by transverse stirrups. Lead lengths of 0.5 and 4.0 in. (13 and $102 \mathrm{~mm}$ ) were used in Groups 5-8 and Group 9, respectively. Straight auxiliary No. 6 flexural reinforcement was used in Groups 5, 6, and 9. Hooked auxiliary reinforcement was used in Groups 7 and 8.

The test results described in the following sections show that relative rib area has a dominant effect on the load-slip response of all bars, independent of rib height. An increase in relative rib area results in an increase in the stiffness of the initial portion of the load-slip curve, matching the obser- 

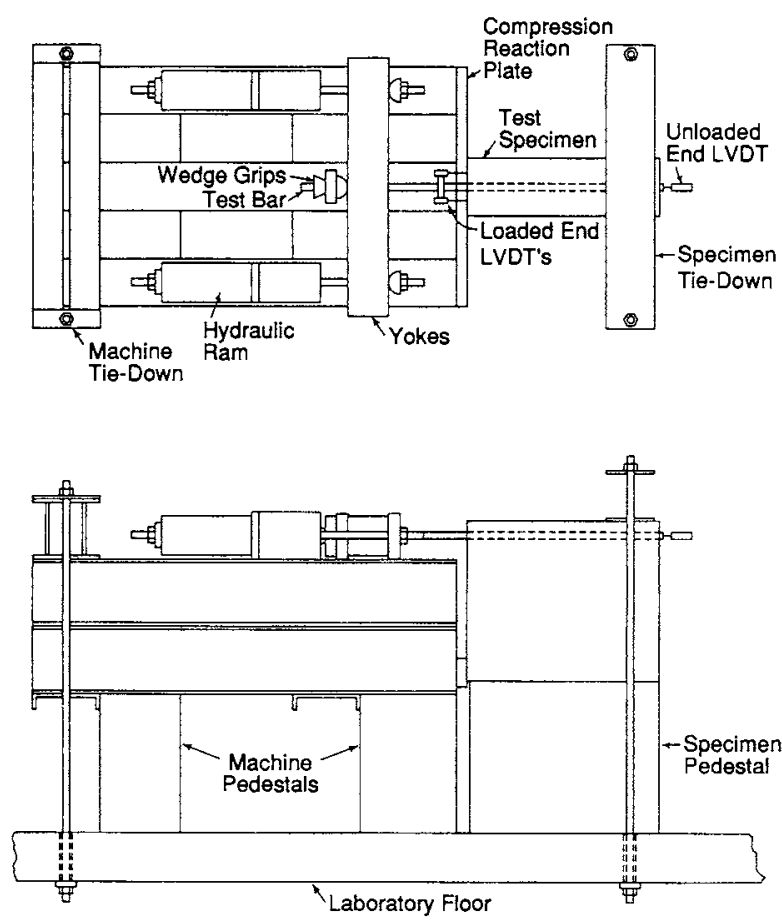

Fig. 3-Schematic of test apparatus

vations of Clark $(1946 ; 1949)$. The test results also show that the effect of relative rib area on bond strength depends on the degree of confinement provided to the reinforcing bar. For bars not confined by transverse reinforcement or high concrete cover, differences in relative rib area have little effect on bond strength. However, the addition of transverse reinforcement or an increase in the confinement provided by the concrete results in a significant increase in bond strength with increasing relative rib area. The details of specimen behavior follow.

Test variables and bond strengths are summarized in Table 3. Full details are presented in Appendix B* and by Darwin and Graham (1993).

\section{Load-slip response}

Average load versus unloaded end slip curves for bars with rib heights of 0.075 in. $(1.91 \mathrm{~mm})$ in Groups 5 and 6 and Group 9 are shown in Fig. 4 and 5, respectively. The curves are representative of bars with other rib heights.

For bars with 2-in. (51-mm) cover and without transverse reinforcement, the curves (Fig. 4) rise steeply and then flatten out as the peak load is attained. For bars with transverse reinforcement (Fig. 4) or additional concrete confinement (Fig. 5), the load-unloaded end slip curves initially rise steeply, reach a plateau at a load of 30 to 40 kips (133 to $178 \mathrm{kN}$ ) and begin to rise again only after significant additional slip until the peak load is attained. The plateau occurs in conjunction with the separation of portions of concrete on the front or top surfaces of the test specimens, lowering the effective bond stiffness and allowing the additional bar movement. The separation of the concrete, however, does not represent the maximum capacity of the specimens, and only

*The appendixes are available in xerographic or similar form from ACI headquarters, where they will be kept permanently on file, at a charge equal to the cost of reproduction plus handling at time of request.

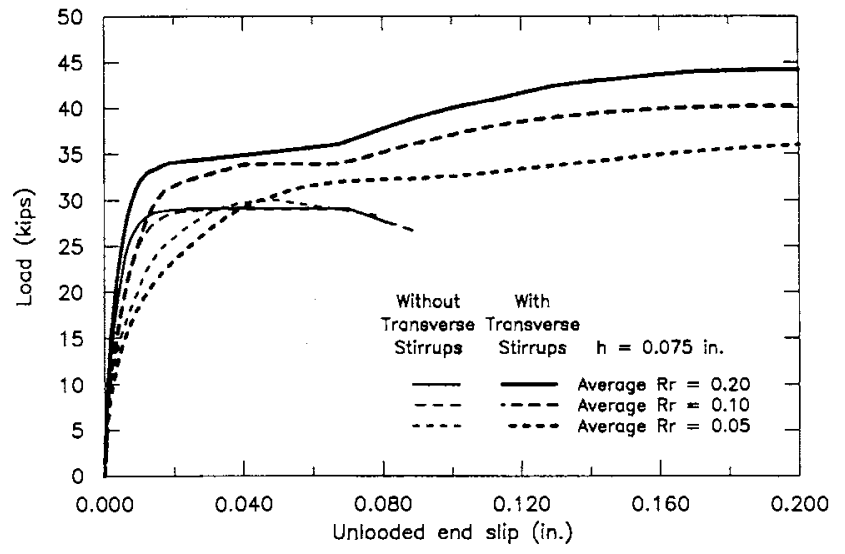

Fig. 4-Average load-unloaded end slip curves for test bars with rib height $h=0.075$ in. and relative rib areas $=0.20$, 0.10 , and 0.05 from Groups 5 and 6 (cover $=2 \mathrm{in}$., lead length $=1 / 2$ in., bonded length $=12 \mathrm{in}$. $)(1 \mathrm{kip}=4.45 \mathrm{kN}$; $1 \mathrm{in} .=25.4 \mathrm{~mm}$ )

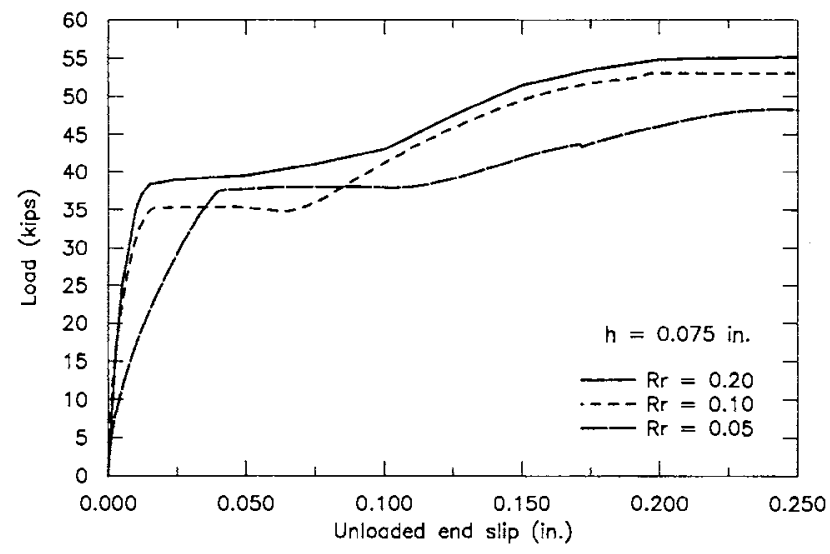

Fig. 5-Average load-unloaded end slip curves for test bars not confined by transverse reinforcement with rib height $h$ $=0.075$ in. and relative rib areas $=0.20,0.10$, and 0.05 from Group 9 (cover $=3$ in., lead length $=4$ in., bonded length $=81 / 2 \mathrm{in}$.) $(\mathrm{l} \mathrm{kip}=4.45 \mathrm{kN} ; 1 \mathrm{in} .=25.4 \mathrm{~mm})$

after additional slip is the maximum capacity of these specimens attained.

A comparison of load-slip response based on relative rib area shows that, for all test groups, the higher $R_{r}$, the higher the initial stiffness of the load-slip curve. For similar degrees of confinement, the initial stiffness appears to depend on $R_{r}$, independent of rib height (Darwin and Graham 1993). The two higher relative rib areas, in general, produce similar curves, with the 0.20 relative rib area bars producing slightly stiffer curves than those with $R_{r}=0.10$. Bars with $R_{r}=0.05$ show significantly more slip than those with the higher relative rib areas. The conventional reinforcing bars (not shown here), with $R_{r}=0.07$, showed unloaded end slips between those obtained for $R_{r}=0.05$ and 0.10 . The high stiffness and low slip obtained with higher values of $R_{r}$ may prove useful in reducing the rate of degradation of reinforced concrete members subjected to severe cyclic loading.

\section{Failure modes}

Cracking-A splitting failure was observed in all tests. The nature of the failure was brittle or ductile, depending on 
Table 3-Summary of test results

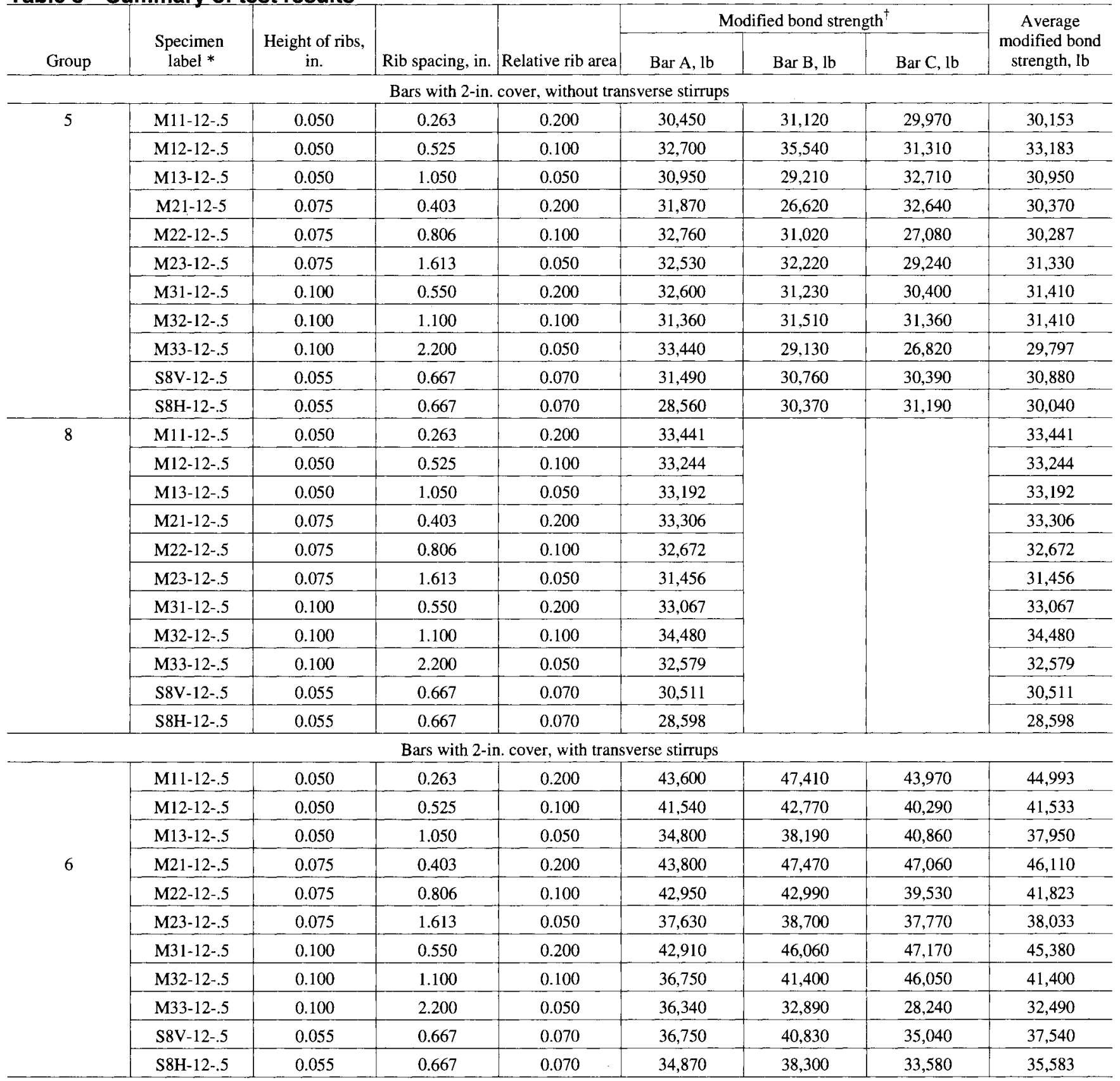

\section{*Specimen label:}

$\mathrm{H}=$ rib height designation: $1=$ low, 0.05 in.; $2=$ medium, 0.075 in. ; $3=$ high, 0.10 in.; $X=$ rib spacing designation: $1=$ small; $2=$ medium; $3=$ large; $O$

$=$ orientation of longitudinal rib $\mathrm{V}=$ vertical; $\mathrm{H}=$ horizontal $; \mathrm{B}=$ bonded length, in.; $\mathrm{L}=$ lead length, in.

1. Machined bars (MHX-B-L); 2. S-pattern \#8 bars (S89-B-L).

${ }^{\dagger}$ Modified bond strength $=$ bond strength $\left(5000 / f_{c}^{\prime}\right)^{1 / 2}$.

$1 \mathrm{lb}=4.448 \mathrm{~N}$; 1 in. $=25.4 \mathrm{~mm}$.

the absence or presence of transverse stirrups. As illustrated in Fig. 3, the specimens were tested in an inverted position. The descriptions that follow refer to the specimen as oriented for the test, with the test bar at the top of the specimen.

For specimens without transverse stirrups and bars with 2-in. (51-mm) cover (Groups 5 and 8), failure was preceded by the initiation of a crack above the test bar, running parallel to the bar, vertically through the cover along the top surface of the specimens, accompanied by one or two cracks visible on the front face of the specimen below the bar. For bars with 3-in. (76-mm) cover (Group 9), a major horizontal crack formed prior to failure. The crack intercepted the test bar and the two auxiliary No. 6 bars. Cracking patterns for specimens with transverse stirrups (Groups 6 and 7) were similar to those observed for specimens with 2-in. $(51-\mathrm{mm})$ cover, without transverse stirrups (Groups 5 and 8). However, specimens with transverse stirrups exhibited more extensive transverse cracking on the top and front surfaces of the specimens.

Local crushing-Concrete was removed after completion of the tests to observe local failure around the test bars for specimens without transverse stirrups. This could not be done for specimens with transverse stirrups because the process 
Table 3-Summary of test results, continued

\begin{tabular}{|c|c|c|c|c|c|c|c|c|}
\hline \multirow[b]{2}{*}{ Group } & \multirow[b]{2}{*}{$\begin{array}{c}\text { Specimen } \\
\text { label* }\end{array}$} & \multirow[b]{2}{*}{$\begin{array}{l}\text { Height of ribs, } \\
\text { in. }\end{array}$} & \multirow[b]{2}{*}{ Rib spacing, in. } & \multirow[b]{2}{*}{ Relative rib area } & \multicolumn{3}{|c|}{ Modified bond strength ${ }^{\dagger}$} & \multirow{2}{*}{$\begin{array}{c}\text { Average } \\
\text { modified bond } \\
\text { strength, lb }\end{array}$} \\
\hline & & & & & $\mathrm{Bar} \mathrm{A}, \mathrm{lb}$ & $\mathrm{Bar} \mathrm{B}, \mathrm{lb}$ & $\mathrm{Bar} \mathrm{C}, \mathrm{lb}$ & \\
\hline \multicolumn{9}{|c|}{ Bars with 2 -in. cover, with transverse stirrups, continued } \\
\hline \multirow{7}{*}{7} & M12-12-.5 & 0.50 & 0.525 & 0.100 & 45,570 & & & 45,570 \\
\hline & M13-12.5 & 0.50 & 1.050 & 0.050 & 40,500 & & & 40,500 \\
\hline & M22-12-.5 & 0.75 & 0.806 & 0.100 & 47,670 & & & 47,670 \\
\hline & $\mathrm{M} 23-12-.5$ & 0.75 & 1.613 & 0.050 & 40,490 & & & 40,490 \\
\hline & M31-12-.5 & 0.100 & 0.550 & 0.200 & 46,980 & & & 46,980 \\
\hline & M32-12-.5 & 0.100 & 1.100 & 0.100 & $\underline{47,250}$ & & & 47,250 \\
\hline & M33-12-.5 & 0.100 & 2.200 & 0.050 & 41,970 & & & 41,970 \\
\hline \multirow[t]{9}{*}{9} & M11-8.5-4 & 0.50 & 0.263 & 0.200 & 50,716 & 45,319 & & 48,017 \\
\hline & M12-8.5-4 & 0.50 & 0.525 & 0.100 & 49,957 & 42,530 & & 46,244 \\
\hline & M13-9.5-4 & 0.50 & 1.050 & 0.50 & 45,015 & 42,331 & & 43,673 \\
\hline & M21-8.5-4 & 0.75 & 0.403 & 0.200 & 50,286 & & & 50,286 \\
\hline & M22-8.5-4 & 0.75 & 0.806 & 0.100 & 48,651 & & & 48,651 \\
\hline & M23-8.5-4 & 0.75 & 1.613 & 0.50 & 44,110 & & & 44,110 \\
\hline & M31-8.5-4 & 0.100 & 0.550 & 0.200 & 46,212 & 47,212 & 48,805 & 47,409 \\
\hline & M32-8.5-4 & 0.100 & 1.100 & 0.100 & 47,363 & 45,419 & 34,462 & 42,415 \\
\hline & \multicolumn{5}{|c|}{ Average without Bar C } & & - & 46,391 \\
\hline
\end{tabular}

\section{*Specimen label:}

$\mathrm{H}=$ rib height designation: $1=$ low, 0.05 in.; $2=$ medium, 0.075 in. $; 3=$ high, 0.10 in.; $\mathrm{X}=$ rib spacing designation: $1=$ small; $2=$ medium; $3=1$ large; $\mathrm{O}$ = orientation of longitudinal rib V = vertical; $\mathrm{H}=$ horizontal; $\mathrm{B}=$ bonded length, in.; $\mathrm{L}=$ lead length, in.

1. Machined bars (MHX-B-L); 2. S-pattern \#8 bars (S89-B-L).

${ }^{\dagger}$ Modified bond strength $=$ bond strength $\left(5000 / f_{c}{ }^{\prime}\right)^{1 / 2}$.

$1 \mathrm{lb}=4.448 \mathrm{~N} ; 1$ in. $=25.4 \mathrm{~mm}$.

of removing the test bars from these specimens involved destruction of the concrete and prevented clear observations from being made.

Concrete surrounding the loaded side of the ribs was crushed as the bar slipped under load. For specimens with ribs spacings up to $1 / 2 \mathrm{in}$. (13 $\mathrm{mm})$, practically all of the concrete between the ribs was crushed. For specimens with rib spacings greater than $1 / 2$ in. $(13 \mathrm{~mm})$, the extent of the crushing varied from $1 / 4$ to $1 / 2$ in. ( 6 to $13 \mathrm{~mm}$ ) in front of the loaded face of the ribs.

Concrete powder was found against the loaded face of some of the ribs. The angle between the surface of the concrete powder and the bar shaft ranged between 17 and $40 \mathrm{deg}$ (Fig. 6 ). The lower angles were observed on the 0.05 in. $(1.27-\mathrm{mm})$ ribs, while the higher angles were observed for the 0.075 and 0.10 in. (1.91 and 2.54-mm) ribs.

\section{Bond strength}

The bond strengths obtained for test specimens in Groups 5 and 6,7 and 8, and 9 are presented in Fig. 7, 8, and 9, respectively. Each data point in Fig. 7 represents the average of three test results. The data points in Fig. 8 represent individual test results, and the data points in Fig. 9 represent one or the average of two or three test specimens. Specific values are presented in Table 3 and Appendix B.

Since concrete strengths range from 4500 to $6000 \mathrm{psi}$ (31 to $41 \mathrm{MPa}$ ), the test results are modified to allow individual tests to be compared on an equitable basis. Modified bond strengths are obtained by normalizing the test results with respect to a nominal concrete strength of 5,000 psi ( $34 \mathrm{MPa}$ ), using the assumption that, within the concrete strength range used, bond strength is proportional to the square root of the compressive strength. Thus, bond strengths are multiplied by $\left(5000 / f_{c}^{\prime}\right)^{1 / 2}\left[\left(34 / f_{c}^{\prime}\right)^{1 / 2}\right]$.

Bars not confined by transverse reinforcement-As illustrated in Fig. 7 and 8, a significant difference in load-slip behavior, as a function of relative rib area $R_{r}$, does not always translate into higher strength. For the specimens without transverse reinforcement, bond strengths are independent of deformation pattern, although most of the prototype bars 


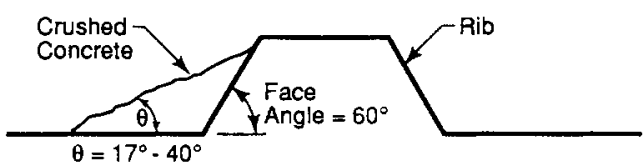

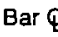

Note: Not to Scale

Fig. 6-Schematic of rib and crushed concrete after failure

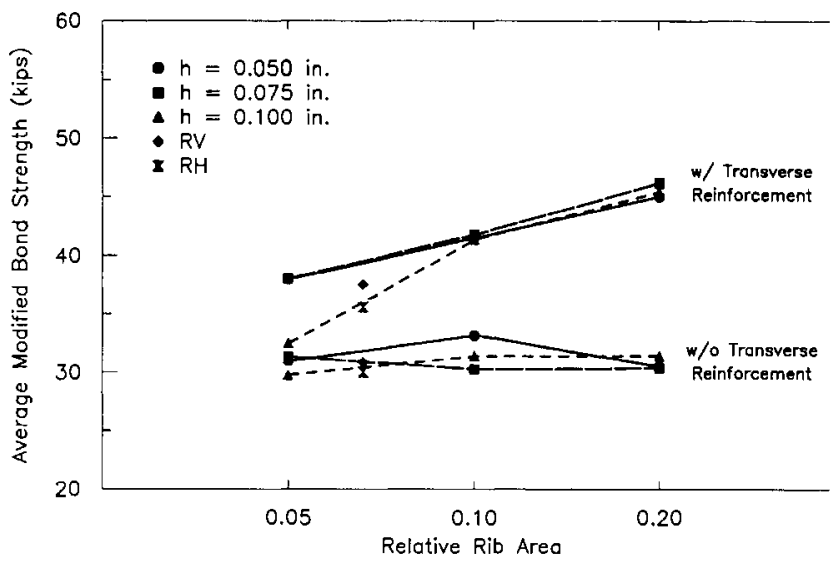

Fig. 7-Average modified bond strength versus relative rib area comparing the effects of confinement provided by transverse reinforcement -Groups 5 and 6 (cover $=2$ in., lead length $=1 / 2$ in., bonded length $=12 \mathrm{in}).(1 \mathrm{kip}=4.45 \mathrm{kN}$; 1 in. $=25.4 \mathrm{~mm}$ )

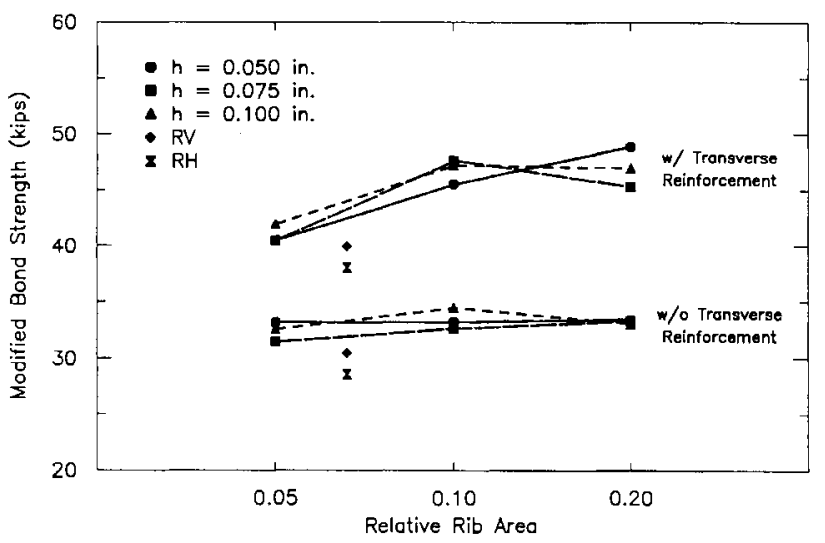

Fig. 8-Modified bond strength versus relative rib area comparing the effects of confinement provided by transverse reinforcement. Beam-end test specimens modified to include hooked auxiliary flexural reinforcement - Groups 7 and 8 (cover $=2$ in., lead length $=1 / 2$ in., bonded length $=12$ in.) $(1 \mathrm{kip}=4.45 \mathrm{kN} ; \mathrm{in} .=25.4 \mathrm{~mm})$

exhibit higher strengths than the conventional reinforcing bars, marked RV and RH. In these cases, the bars were subject to low confining stresses and acted as wedges, causing the concrete to split at the time of failure. The results suggest that there is apparently little difference in the wedging effect, as a function of rib height and spacing. The lower strength obtained by the conventional bars may be tied to the lower

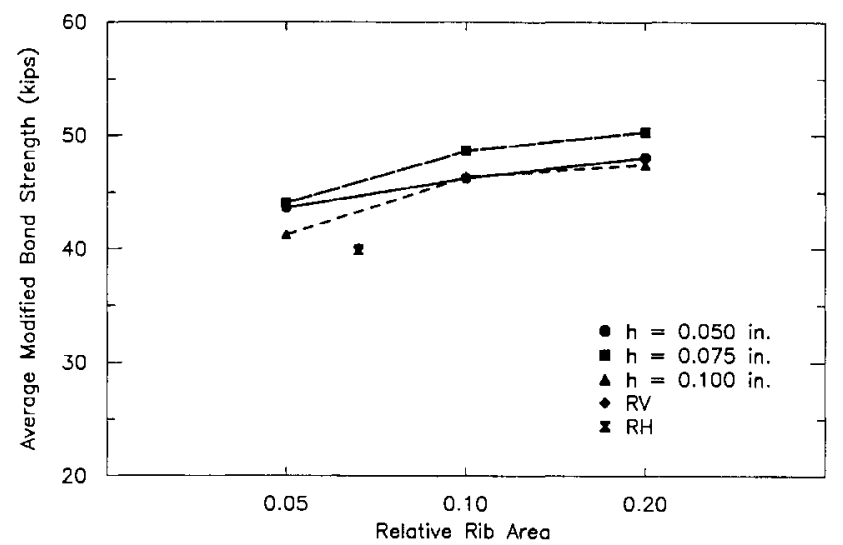

Fig. 9-Average modified bond strength versus relative rib area for reinforing bars with added concrete confinement Group 9 (cover $=3$ in., lead length $=4$ in.; bonded length $=81 / 2 \mathrm{in}$. $(1 \mathrm{kip}=4.45 \mathrm{kN}, 1 \mathrm{in} .=25.4 \mathrm{~mm})$

face angle of the ribs, which may cause these bars to act as somewhat more efficient wedges than the machined bars. It can also be observed that the conventional bars with the longitudinal ribs oriented in the vertical position (RV) consistently provide higher bond strengths than the conventional bars with the longitudinal ribs oriented in a horizontal position (RH). This may be due to the fact that the specimens fail principally by vertical cracking and the vertical orientation of the longitudinal ribs brings more of the surface area of the transverse ribs to bear on the concrete (sides of the cracks) at the time of failure.

Bars confined by transverse reinforcement-In contrast to the bars without transverse reinforcement, the bars with transverse reinforcement (Groups 6 and 7) exhibit a significant effect of deformation pattern on bond strength. In all cases, bond strength increases significantly with the addition of transverse reinforcement; however, that increase is generally greater, the greater the relative rib area. For the tests illustrated in Fig. 7, the bars with the lowest value of $R_{r}(0.05)$ exhibit a 25 percent increase in bond strength due to confinement. As relative rib area increases, the additional bond strength provided by the confinement increases up to 50 percent for $R_{r}=0.20$. With the exception of the bars with $R_{r}=0.05$ and rib height $=0.10$ (rib spacing $=2.20$ in.) shown in Fig. 7, relative rib area appears to be the primary controlling factor in the added bond strength, i.e., relative rib area rather than rib height and/or rib spacing appears to be the factor controlling the increase in bond capacity. The added strength obtained for the conventional reinforcement $\left(R_{r}=0.07\right)$ is below that obtained for most of the machined bars with $R_{r}$ $=0.05$. As shown in Fig. 8, similar results are obtained for the specimens with hooked auxiliary reinforcement. The hooked No. 6 bars resulted in a 2 to 3 -kip ( 9 to $13-\mathrm{kN}$ ) increase in bond strength for bars without transverse reinforcement and a similar increase in bond strength for bars with transverse reinforcement, up to a maximum of 45 to 48 kips (200 to $214 \mathrm{kN}$ ). This leveling off appears to be due primarily to the test specimen rather than the deformation geometry. As a result, the tests in Group 9 returned to the original reinforcement configuration. 
Bars with additional concrete confinement-To evaluate the effects of additional concrete confinement, the specimen configuration shown in Fig. 1a was modified by raising the position of the test bar and the auxiliary reinforcement by 1 in. $(25 \mathrm{~mm})$ and increasing the lead length to 4 in. $(102 \mathrm{~mm})$, while reducing the bonded length to $81 / 2$ in. $(216 \mathrm{~mm})$ [total embedment remained at $12 \frac{1}{2} \mathrm{in}$. $\left.(318 \mathrm{~mm})\right]$ to limit the total bond force. The results (Fig. 9) illustrate that there is a strong relationship between bond strength and relative rib area if there is added confinement provided by the concrete. The results illustrated in Fig. 9 represent all but two of the test specimens in Group 9. The two specimens, M32-8.5-4C and M33-8.5-4C, are excluded because they had unusually low strengths, 12 and 6 kips (53 and $27 \mathrm{kN}$ ), respectively, below other bars with the same test parameters.

A comparison of Fig. 9 with the results for Groups 5 and 8 in Fig. 7 and 8, respectively, shows that added concrete confinement significantly increases bond strength and that the higher the relative rib area, the greater the increase. For the results illustrated in Fig. 9, the average bond strengths increase by 40,49 , and 58 percent for $R_{r}=0.05,0.10$, and 0.20 , respectively, compared to the specimens in Group 5 (Fig. 6). As observed for the test results shown in Fig. 7 and 8 , the bond strengths obtained by the conventional reinforcement are below those obtained by the machined bars, increasing by an average of just 31 percent, compared to similar bars tested in Group 5. In this case, the bond strength obtained by the conventional reinforcement appears to be unaffected by the orientation of the longitudinal ribs, perhaps because the principal failure crack was horizontal.

Overall, comparisons between Fig. 7 and 9 suggest that increasing $R_{r}$ for bars in practice will result in even greater improvements in bond strength with added cover and bar spacing than can be obtained currently.

\section{DISCUSSION}

The most important observations in the current study involve 1) the conditions under which deformation pattern plays a role in bond strength and 2) the effect of the relative rib area, $R_{r}$, on bond force-slip relationships and bond strength.

Within the range of the deformation parameters evaluated in this study, deformation pattern has virtually no effect on bond strength when a splitting failure of the concrete governs. This matches the earlier observations of Losberg and Olsson (1979), as well as the statistical evaluations by Orangun, Jirsa, and Breen $(1975 ; 1977)$ and Darwin et al. (1992a; 1992b). Under these conditions, a deformed reinforcing bar behaves as a wedge due to the nature of the loading it imposes on the concrete, causing the concrete to split. The wedging action is not sethitive to the details of the deformation pattern. Under conditions of increased confinement (as in a standard pullout test or with the addition of transverse reinforcement or higher concrete cover and bar spacing), the greater the rib bearing area, the higher the bond strength. Thus, with additional confinement provided by either transverse reinforcement or additional concrete, bond strength increases significantly with increases in the relative rib area. This matches the observations of Losberg and Olsson (1979),
Soretz and Holzenbein (1979), and Kimura and Jirsa (1992). The current study has not established an upper limit on the relative rib area beyond which no improvement in bond strength occurs; there is likely an upper limit, based on practical considerations of bar production and concrete placement. However, since $R_{r}$ for production bars is typically less than 0.08 (Choi et al. 1990), there is considerable room for improvement.

The close relationship between the shape of the load-slip curve and $R_{r}$ matches the observations of Clark $(1946 ; 1949)$; under all conditions, the initial stiffness of the curve increases with increasing relative rib area. As mentioned earlier, the high load-slip stiffness of bars with high values of $R_{r}$ could prove to be useful for structures subjected to cyclic loading.

There are some aspects of the current study that do not agree completely with earlier observations. Rehm (1957; 1961) found a relationship between the ratio of rib spacing to rib height and the nature of bond failure. For spacing/height ratios less than 7 , Rehm observed that a pullout failure will occur, while for spacing/height ratios greater than 10 , a splitting failure will occur. In the current study, splitting failures occurred in all cases, even down to spacing/height ratios of 5.26 .

Losberg and Olsson (1979) observed that bond capacity decreased once ribs become closer than about two-thirds of the bar diameter. This did not occur in the current study. No degradation in bond strength was observed for rib spacings as close as 0.263 bar diameter. The differences in these observations may be due, in part, to the effect of the width of the concrete between the deformations. In the current study, deformation widths are relatively small, allowing adequate concrete widths (and therefore strength) between deformations. If deformation width were increased at a constant spacing, the amount of concrete available to carry bond shear stress would be decreased, which might decrease bond strength. This factor will be addressed in a later paper.

Lutz and Gergely (1967) observed that crushed concrete in front of ribs produced an effective rib face angle of 30 to $40 \mathrm{deg}$. In the current study, that angle ranged from 17 to 40 deg. The lower angles were observed on bars with rib heights of $0.05 \mathrm{in} .(1.27 \mathrm{~mm})$. The higher angles were observed for bars with rib heights of 0.075 and 0.10 in. (1.91 and 2.54 $\mathrm{mm}$ ). In spite of the differences in effective face angle, overall response was a function of relative rib area. In the current study, there does not seem to be a relationship between the angle of the crushed concrete and bond behavior.

In addition to the effect of the width of concrete between ribs, there are at least two other questions that have not been answered. First, it is not clear why the conventional reinforcing provided lower bond strengths than the machined reinforcing bars when confinement was provided by transverse reinforcement or additional concrete cover. Second, since the nominal diameter of the reinforcing bars used in this study was constant, it is not clear whether the observed effect of relative rib area is truly nondimensional or a function of the bearing area of the ribs per unit length of the bar.

\section{SUMMARY AND CONCLUSIONS}

The effect of deformation pattern on bond strength was studied using 1-in. (25.4-mm) diameter machined bars with 
deformation heights of $0.05,0.075$, and $0.10 \mathrm{in.}(1.27,1.91$, and $2.54 \mathrm{~mm}$ ) and deformation spacings ranging from 0.263 to 2.2 in. $(6.7$ to $56 \mathrm{~mm})$. The combinations of rib height and spacing produced relative rib areas of $0.20,0.10$, and 0.05 for each deformation height. Conventional reinforcing bars were also studied. The effect of deformation pattern was evaluated using beam-end specimens with varying degrees of confinement provided to the test bars. Degrees of confinement were: 1) 2-in. $(51-\mathrm{mm})$ cover without confining transverse stirrups, 2) 2-in. (51-mm) cover with confining transverse stirrups, and 3) 3-in. (76-mm) cover without confining transverse stirrups. Test bars with 2 -in. $(51-\mathrm{mm})$ cover had an initial unbonded length of $1 / 2 \mathrm{in} .(13 \mathrm{~mm})$ and a bonded length of $12 \mathrm{in.}(305 \mathrm{~mm})$. Bars with 3-in. (76-mm) cover had an initial unbonded length of 4 in. $(102 \mathrm{~mm})$ and a bonded length of $8 \frac{1}{2}$ in. $(216 \mathrm{~mm})$.

The following conclusions are based on the results and analyses presented in this paper for the range of the parameters evaluated.

1. The bond force-slip response of reinforcing bars is a function of the relative rib area of the bars, independent of the specific combination of rib height and rib spacing.

2. Under all conditions of bar confinement, the initial stiffness of the load-slip curve increases with an increase in the relative rib area.

3. Under conditions of relatively low confinement, in which bond strength is governed by splitting of the concrete, bond strength is independent of deformation pattern.

4. Under conditions in which additional bar confinement is provided by transverse reinforcement or higher covers and lead lengths, bond strength increases compared to the bond strength of bars with less confinement. The magnitude of the increase in bond strength increases with an increase in the relative rib area.

\section{ACKNOWLEDGMENTS}

Funding for this research was provided by the Civil Engineering Research Foundation under CERF Contract No. 91-N6002, the National Science Foundation under NSF Grant No. MSS-9021066, and the Reinforced Concrete Research Council under RCRC Project 56. Support was also provided by $\mathrm{ABC}$ Coating Company, Inc., Birmingham Steel Corporation, Chaparral Steel Company, Florida Steel Corporation, Morton Powder Coatings, Inc., North Star Steel Company, and 3M Corporation. Form release agent, curing compound, and mounting hardware were supplied by Richmond Screw Anchor Company. Conventional reinforcing steel was supplied by Structural Metals, Inc.

\section{REFERENCES}

ASTM A 305-47T, "Tentative Specifications for Minimum Requirements for Deformations of Deformed Steel Bars for Concrete Reinforcement, American Society for Testing and Materials, Philadelphia, 1947.

ASTM A 305-49, "Specifications for Minimum Requirements for Deformations of Deformed Steel Bars for Concrete Reinforcement" American Society for Testing and Materials, Philadelphia, 1949.

ASTM A 311/A311M-90b. "Specification for Stressed-Relieved ColdDrawn Carbon Steel Bars Subject to Mechanical Property Requirements," 1992 Annual Book of ASTM Standards, V. 1.05, American Society for Testing and Materials, Philadelphia, pp. 145-148.

ASTM A 615-90. "Standard Specification for Deformed and Plain Billet-Steel Bars for Concrete Reinforcement," 1992 Annual Book of ASTM Standards, V. 1.04, American Society for Testing and Materials, Philadelphia, pp. 389-392.
ASTM A 616/A 616M-90, "Standard Specification for Rail-Steel Deformed and Plain Bars for Concrete Reinforcement," 1992 Annual Book of ASTM Standards, V. 1.04, American Society for Testing and Materials, Philadelphia, pp. 397-401.

ASTM A 617/A 617M-90, "Standard Specification for Axle-Steel Deformed and Plain Bars for Concrete Reinforcement," 1992 Annual Book of ASTM Standards, V. 1.04, American Society for Testing and Materials, pp. 402-405

ASTM A 706/A 706M-90, "Standard Specification for Low-Alloy Steel Deformed Bars for Concrete Reinforcement, 1992 Annual Book of ASTM Standards, V. 1.04, American Society for Testing and Materials, Philadelphia, pp. $488-491$.

Brettmann, Barrie B; Darwin, David; and Donahey, Rex C., 1984. "Effect of Superplasticizers on Concrete - Steel Bond Strength," SL Report 84-1, University of Kansas Center for Research, Lawrence, Apr., 32 pp.

Brettmann, Barrie B; Darwin, David; and Donahey, Rex C., 1986. "Bond of Reinforcement to Superplasticized Concrete," ACI JournaL, Proceedings V. 83, No. 1, Jan.-Feb., pp. 98-107.

Chinn, James; Ferguson, Phil M.; and Thompson, J. Neils, 1955. "Lapped Splices in Reinforced Concrete Beams," ACI Journal, Proceedings V. 52, No. 2, Oct., pp. 201-214.

Choi, Oan Chul; Hadje-Ghaffari, Hossain; Darwin, David; and McCabe, Steven L., 1990. "Bond of Epoxy-Coated Reinforcement to Concrete: Bar Parameters," SL Report 90-1, University of Kansas Center for Research, Lawrence, Jan., 43 pp.

Choi, Oan Chul; Hadje-Ghaffari, Hossain; Darwin, David; and McCabe, Steven L., 1991. "Bond of Epoxy-Coated Reinforcement: Bar Parameters," ACI Materials Journal, V. 88, No. 2, Mar-Apr., pp. 207-217.

Clark, A. P., 1946. "Comparative Bond Efficiency of Deformed Concrete Reinforcing Bars," ACI Journal, Proceedings V. 43, No. 4, Dec., pp. $381-400$

Clark, A. P., 1949. "Bond of Concrete Reinforcing Bars," ACI JouRnal, Proceedings V. 46, No. 3, Nov., pp. 161-184.

Darwin, D., McCabe, S. L., Hadje-Ghaffari, H., and Choi, O. C., 1990. "Bond Strength of Epoxy-Coated Reinforcement to Concrete-An Update," Proceedings, ASCE Materials Congress, Aug., pp. 115-124.

Darwin, D.; McCabe, S. L.; Idun, E. K.; and Schoenekase, S. P., 1992a. "Development Length Criteria: Bars without Transverse Reinforcement," SL Report 92-1, University of Kansas Center for Research, Lawrence, Apr., 62 pp.

Darwin, D.; McCabe, S. L.; Idun, E. K.; and Schoenekase, S. P., 1992b. "Development Length Criteria: Bars Not Confined by Transverse Reinforcement," ACI Structural Journal, V. 89, No. 6, Nov.-Dec., pp. 709-720.

Darwin, David, and Graham, Ebenezer K., 1993. "Effect of Deformation Height and Spacing on Bond Strength of Reinforcing Bars," SL Report 93-1, University of Kansas Center for Research, Lawrence, Jan., 68 pp.

DIN., 1986. "Reinforcing Steel," (DIN 488), (English translation), 29 pp.

Donahey, Rex C., and Darwin, David, 1983. "Effects of Construction Procedures on Bond in Bridge Decks," SM Report No. 7, University of Kansas Center for Research, Lawrence, Jan., 129 pp.

Donahey, Rex C. and Darwin, David, 1985. "Bond of Top-Cast Bars in Bridge Decks, " ACI JourNaL, Proceedings V. 82, No. 1, January-February, pp. 57-66.

Ferguson, Phil M., and Thompson, J. Neils, 1962. "Development Length of High Strength Reinforcing Bars in Bond," ACI Journal, Proceedings V. 59, No. 7, July, pp. 887-922.

Hadje-Ghaffari, Hossain; Darwin, David; and McCabe, Steven L., 1991. "Effects of Epoxy Coating on Bond of Reinforcing Steel to Concrete," SM Report No. 28, University of Kansas Center for Research, Lawrence, July, $288 \mathrm{pp}$

Hadje-Ghaffari, H.; Choi, O. C.; Darwin, D.; and McCabe, S. L., 1992. "Bond of Epoxy-Coated Reinforcement to Concrete: Cover, Casting Position, Slump, and Consolidation," SL Report 92-3, University of Kansas Center for Research, Lawrence, June, 42 pp.

ISO, 1990. "Steel for the Reinforcement of Concrete - Part 2: Ribbed Bars," (ISO/DIS 6935-2), International Organization for Standardization, $10 \mathrm{pp}$.

JIS, 1975. "Steel Bars for Concrete Reinforcement,"(JIS G 3112) Japanese Industrial Standard, (English translation), $9 \mathrm{pp}$.

ACI Structural Journal / November-December 1993 
Johnston, David W., and Zia, Paul, 1982. "Bond Characteristics of Epoxy Coated Reinforcing Bars," Report No. FHWA-NC-82-002, Federal Highway Administration, Washington, DC, 163 pp.

Kimura, Hideka, and Jirsa, James O., 1992. "Effects of Bar Deformation and Concrete Strength on Bond of Reinforcing Steel to Concrete," PMFSEL Report No. 92-4, Phil M. Ferguson Structural Engineering Laboratory, University of Texas at Austin, Sept., 78 pp.

Losberg, Anders, and Olsson, Per-Ake, 1979. "Bond Failure of Deformed Reinforcing Bars Based on the Longitudinal Splitting Effect of the Bars," ACI Journal, Proceedings V. 76, No. 1, Jan., pp. 5-18.

Lutz, L. A.; Gergely, P,; and Winter, G., 1966. "Mechanics of Bond and Slip of Deformed Reinforcing Bars in Concrete," Report No. 324, Department of Structural Engineering, Cornell University, Aug., 306 pp.

Lutz, L. A., and Gergely, P., 1967. "Mechanics of Bond and Slip of Deformed Bars in Concrete," ACI Journal, Proceedings V. 64, No. 11, Nov., pp. 711-721.

Menzel, Carl A., 1939. "Some Factors Influencing Results of Pull-Out Bond Tests," ACI Journal, Proceedings V. 35, No. 10, June, pp. 517-542.

Menzel, Carl A., 1952. "Effect of Settlement of Concrete on Results of

Pullout Tests," Research Department Bulletin 41, Portland Cement Association, Skiokie, Nov., 49 pp.

Orangun, C. O.; Jirsa, J. O.; and Breen, J. E., 1975. "Strength of Anchored Bars: A Reevaluation of Test Data on Development Length and Splices,"
Research Report No. 154-3F, Center for Highway Research, University of Texas at Austin, Jan., $78 \mathrm{pp}$.

Orangun, C. O.; Jirsa, J. O.; and Breen, J. E., 1977. "Reevaluation of Test Data on Development Length and Splices," ACI JournaL, Proceedings, V. 74, No. 3, Mar., pp. 114-122.

Rehm, G., 1957. "Fundamental Law of Bond," Proceedings Symposium on Bond and Crack Formation in Reinforced Concrete (Stockholm), RILEM, Paris, (published by Tekniska Hogskolans Rotaprinttrychkeri, Stockholm,) 1958.

Rehm, G., 1961. "Uber die Grunlagen des Verbundes Zwischen Stahl und Beton." Deutscher Ausschuss fur Stahlbeton, No. 1381, pp. 59, (C \& CALibrary Translation No. 134, 1968. "Basic Principle of the Bond between Steel and Concrete.".

Skorbogatov, S. M., and Edwards, A. D., 1979. "Influence of the Geometry of Deformed Steel Bars on Their Bond Strength in Concrete,"Institute of Civil Engineers, Proceedings, V. 67, Part 2, June, pp. 327-339.

Soretz, S., and Holzenbein, H., 1979. "Influence of Rib Dimensions of Reinforcing Bars on Bond and Bendability," ACI JouRNaL, Proceedings V. 76, No. 1, Jan., pp. 111-127.

Treece, Robert A., and Jirsa, James O., 1989. "Bond Strength of EpoxyCoated Reinforcing Bars," ACI Materials Journal, V. 86, No. 2, Mar.-Apr., pp. 167-174. 
Appendix Al: Concrete Mixture Proportions (Per Cubic Yard)

\begin{tabular}{|c|c|c|c|c|c|}
\hline Nominal & $W / C$ & Cement & Water & \multicolumn{2}{|c|}{ Aggregate } \\
\hline $\begin{array}{l}\text { Strength } \\
\text { (psi) }\end{array}$ & Ratio & (lb) & (lb) & $\begin{array}{l}\text { Fine } \\
\text { ( } \mathrm{lb} \text { ) }\end{array}$ & $\begin{array}{c}\text { Coarse }{ }^{*} \\
(\mathrm{Ib})\end{array}$ \\
\hline 6000 & $\overline{0.41}$ & 550 & 225 & 1564 & 1588 \\
\hline
\end{tabular}

- Kansas River Sand-Lowrence Sand Co., Lawrence, KS.

Bulk Specific Gravity (SSD) $=2.62$ : Absorption $=0.5 \%$ : Fineness Modulus $=2.89$.

- Crushed Limestone - Fogel's Quarry. Ottawa, KS.

Bulk Specific Gravity (SSD) $=2.58$; Absorption $=2.7 \%$; Max. Size $=3 / 4$ in. :

Unit Weight $=90.5 \mathrm{lb} / \mathrm{cu}$. $\mathrm{ft}$.

$\mathrm{l} \mathrm{lb}=0.454 \mathrm{~kg}$

Appendix A2: Concrete Properties

\begin{tabular}{|c|c|c|c|c|c|}
\hline Group & $\begin{array}{l}\text { Slump } \\
\text { (in.) } \\
\end{array}$ & $\begin{array}{c}\text { Concrete } \\
\text { Temperature } \\
\text { (F) }\end{array}$ & $\begin{array}{c}\text { Air } \\
\text { Content } \\
(\%)\end{array}$ & $\begin{array}{c}\text { Age ot } \\
\text { Test } \\
\text { (days) }\end{array}$ & $\begin{array}{l}\text { Av. Comp. } \\
\text { Strength } \\
\text { (psi) }\end{array}$ \\
\hline $5 a$ & $21 / 2$ & 72 & 3.9 & 8 & 4560 \\
\hline $5 b$ & $21 / 2$ & 72 & 3.9 & 9 & 4610 \\
\hline $6 a$ & $21 / 2$ & 75 & 3.9 & 9 & 4600 \\
\hline $6 b$ & 2 & 72 & 3.8 & 9 & 4720 \\
\hline $6 c$ & $13 / 4$ & 65 & 3.2 & 8 & 4530 \\
\hline 7 & 2 & 70 & 3.2 & 9 & 4750 \\
\hline 8 & 2 & 56 & 4.1 & 8 & 4630 \\
\hline $9 a$ & 2 & 49 & 3.2 & 19 & 5990 \\
\hline $9 b$ & 2 & 45 & 3.1 & 10 & 5040 \\
\hline
\end{tabular}

1 in. $=25.4 \mathrm{~mm} ; F=9 / 5 \mathrm{C}+32 ; 1000 \mathrm{psi}=6.894 \mathrm{MPa}$ 
Appendix B: Beam - end Tests

\begin{tabular}{|c|c|c|c|c|c|c|c|c|c|}
\hline$\overline{\overline{\text { Group }}}$ & $\begin{array}{l}\text { Specimen } \\
\text { Label }^{\circ}\end{array}$ & 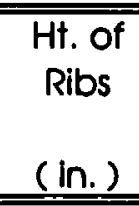 & $\begin{array}{l}\text { Rib } \\
\text { Spacing } \\
\text { (in.) } \\
\end{array}$ & $\begin{array}{l}\text { Rel. } \\
\text { Rib } \\
\text { Area }\end{array}$ & Cover & $\begin{array}{c}\text { Concrete } \\
\text { Strength } \\
\text { (psi) } \\
\end{array}$ & $\begin{array}{l}\text { Bond } \\
\text { Str. } \\
\text { (lb) } \\
\end{array}$ & $\begin{array}{l}\text { Mod. } \\
\text { Bond } \\
\text { Str. ... } \\
\text { (lb) } \\
\end{array}$ & Stimups \\
\hline \multirow[t]{40}{*}{5} & MII-12-.5A & 0.050 & 0.2630 & 0.200 & $21 / 8$ & 4560 & 29080 & 30450 & \\
\hline & MII-12-.5B & 0.050 & 0.2630 & 0.200 & $21 / 8$ & 4610 & 29880 & 31120 & \\
\hline & $M 11-12-.5 C$ & 0.050 & 0.2630 & 0.200 & $21 / 16$ & 4610 & 28780 & 29970 & \\
\hline & Avg. & & & & & & & 30513 & \\
\hline & M12-12-.5A & 0.050 & 0.5250 & 0.100 & $21 / 16$ & 4610 & 31400 & 32700 & \\
\hline & M12-12-.5B & 0.050 & 0.5250 & 0.100 & $21 / 8$ & 4610 & 34130 & 35540 & \\
\hline & MI2-12-.5C & 0.050 & 0.5250 & 0.100 & $21 / 8$ & 4560 & 29900 & 31310 & \\
\hline & Avg. & & & & & & & 33183 & \\
\hline & M13-12-.5A & 0.050 & 1.0500 & 0.050 & $21 / 8$ & 4610 & 29720 & 30950 & \\
\hline & M13-12-.5B & 0.050 & 1.0500 & 0.050 & $23 / 16$ & 4610 & 28050 & 29210 & \\
\hline & M13-12-.5C & 0.050 & 1.0500 & 0.050 & $23 / 16$ & 4560 & 31240 & 32710 & \\
\hline & Avg. & & & & & & & 31427 & \\
\hline & $M 21-12-.5 A$ & 0.075 & 0.4030 & 0.200 & $23 / 8$ & 4610 & 30600 & 31870 & \\
\hline & M21-12-.5B & 0.075 & 0.4030 & 0.200 & $21 / 8$ & 4560 & 25420 & 26620 & \\
\hline & $M 21-12-.5 C$ & 0.075 & 0.4030 & 0.200 & $21 / 8$ & 4610 & 31340 & 32640 & \\
\hline & Avg. & & & & & & & 30377 & \\
\hline & $M 22-12-.5 A$ & 0.075 & 0.8060 & 0.100 & 2 & 4610 & 31460 & 32760 & \\
\hline & $M 22-12-.5 B$ & 0.075 & 0.8060 & 0.100 & $21 / 8$ & 4560 & 29620 & 31020 & \\
\hline & $M 22-12-.5 \mathrm{C}$ & 0.075 & 0.8060 & 0.100 & $21 / 4$ & 4610 & 26000 & 27080 & \\
\hline & Avg. & & & & & & & 30287 & \\
\hline & $M 23-12-.5 \mathrm{~A}$ & 0.075 & 1.6125 & 0.050 & 2 & 4610 & 31240 & 32530 & \\
\hline & M23-12-.5B & 0.075 & 1.6125 & 0.050 & $21 / 16$ & 4560 & 30770 & 32220 & \\
\hline & M23-12-.5C & 0.075 & 1.6125 & 0.050 & $21 / 16$ & 4610 & 28080 & 29240 & \\
\hline & Avg. & & & & & & & 31330 & \\
\hline & M31-12-.5A & 0.100 & 0.5500 & 0.200 & $21 / 16$ & 4560 & 31130 & 32600 & \\
\hline & M31-12-.5B & 0.100 & 0.5500 & 0.200 & $21 / 16$ & 4610 & 29990 & 31230 & \\
\hline & $M 31-12-.5 C$ & 0.100 & 0.5500 & 0.200 & $23 / 16$ & 4560 & 29030 & 30400 & \\
\hline & Avg. & & & & & & & 31410 & \\
\hline & M32-12-.5A & 0.100 & 1.1000 & 0.100 & $15 / 16$ & 4560 & 29950 & 31360 & \\
\hline & M32-12-.5B & 0.100 & 1.1000 & 0.100 & $15 / 16$ & 4610 & 30260 & 31510 & \\
\hline & M32-12-.5C & 0.100 & 1.1000 & 0.100 & $21 / 16$ & 4610 & 30110 & 31360 & \\
\hline & Avg. & & & & & & & 31410 & \\
\hline & M33-12-.5A & 0.100 & 2.2000 & 0.050 & $21 / 8$ & 4610 & 32110 & 33440 & \\
\hline & M33-12-.5B & 0.100 & 2.2000 & 0.050 & $23 / 16$ & 4610 & 27970 & 29130 & \\
\hline & $M 33-12-.5 C$ & 0.100 & 2.2000 & 0.050 & $21 / 8$ & 4610 & 25750 & 26820 & \\
\hline & Avg. & & & & & & & 29797 & \\
\hline & $S 8 V-12-.5 \mathrm{~A}$ & 0.055 & 0.6670 & 0.070 & $21 / 4$ & 4560 & 30070 & 31490 & \\
\hline & $S 8 V-12-.5 B$ & 0.055 & 0.6670 & 0.070 & $23 / 16$ & 4610 & 29540 & 30760 & \\
\hline & S8V-12-.5C & 0.055 & 0.6670 & 0.070 & 2 & 4610 & 29180 & 30390 & \\
\hline & Avg. & & & & & & & 30880 & \\
\hline
\end{tabular}


Appendix B: Beam - end Tests ( Cont'd)

\begin{tabular}{|c|c|c|c|c|c|c|c|c|c|}
\hline Group & $\begin{array}{l}\text { Specimen } \\
\text { Label }\end{array}$ & $\begin{array}{l}\text { Ht. of } \\
\text { Ribs } \\
\text { (in.) }\end{array}$ & $\begin{array}{l}\text { Rib } \\
\text { Spacing } \\
\text { (in.) } \\
\end{array}$ & $\begin{array}{l}\text { Rel. } \\
\text { Rib } \\
\text { Area }\end{array}$ & Cover & $\begin{array}{c}\text { Concrete } \\
\text { Strength } \\
(\mathrm{psi}) \\
\end{array}$ & $\begin{array}{l}\text { Bond } \\
\text { Str. } \\
\text { (Ib) }\end{array}$ & $\begin{array}{l}\text { Mod. } \\
\text { Bond } \\
\text { Str. ... } \\
\text { (lb ) }\end{array}$ & Stirrups \\
\hline 5 & $\begin{array}{l}\text { S8H-12-.5A } \\
\text { S8H-12-.5B } \\
\text { S8H-12-.5C } \\
\text { Avg. }\end{array}$ & $\begin{array}{l}0.055 \\
0.055 \\
0.055\end{array}$ & $\begin{array}{l}0.6670 \\
0.6670 \\
0.6670\end{array}$ & $\begin{array}{l}0.070 \\
0.070 \\
0.070\end{array}$ & $\begin{array}{ll}2 & 1 / 8 \\
2 & 1 / 16 \\
2 & 1 / 16\end{array}$ & $\begin{array}{l}4560 \\
4610 \\
4610\end{array}$ & $\begin{array}{l}27270 \\
29160 \\
29950\end{array}$ & $\begin{array}{l}28560 \\
30370 \\
31190 \\
30040\end{array}$ & \\
\hline 6 & $\begin{array}{l}\text { Ml1-12-.5A } \\
\text { Ml1-12-.5B } \\
\text { Mll-12-.5C } \\
\text { Avg. }\end{array}$ & $\begin{array}{l}0.050 \\
0.050 \\
0.050\end{array}$ & $\begin{array}{l}0.2630 \\
0.2630 \\
0.2630\end{array}$ & $\begin{array}{l}0.200 \\
0.200 \\
0.200\end{array}$ & $\begin{array}{ll}2 & 1 / 8 \\
2 & 1 / 8 \\
2 & 1 / 16\end{array}$ & $\begin{array}{l}4600 \\
4720 \\
4530\end{array}$ & $\begin{array}{l}41820 \\
46060 \\
41850\end{array}$ & $\begin{array}{l}43600 \\
47410 \\
43970 \\
44993\end{array}$ & $\begin{array}{l}4-\# 3 \\
4-\# 3 \\
4-\# 3\end{array}$ \\
\hline & $\begin{array}{l}\text { M12-12-.5A } \\
\text { M12-12-.5B }\end{array}$ & $\begin{array}{l}0.050 \\
0.050\end{array}$ & $\begin{array}{l}0.5250 \\
0.5250\end{array}$ & $\begin{array}{l}0.100 \\
0.100\end{array}$ & $\begin{array}{ll}2 & 1 / 8 \\
1 & 15 / 16\end{array}$ & $\begin{array}{l}4600 \\
4720\end{array}$ & $\begin{array}{l}39840 \\
41560\end{array}$ & $\begin{array}{l}41540 \\
42770\end{array}$ & $\begin{array}{l}4-\# 3 \\
4-\# 3\end{array}$ \\
\hline & $\begin{array}{l}\text { M12-12-.5C } \\
\text { Avg. }\end{array}$ & 0.050 & 0.5250 & 0.100 & 1 15/16 & 4530 & 38350 & $\begin{array}{l}40290 \\
37700\end{array}$ & $4-\# 3$ \\
\hline & M13-12-.5A & 0.050 & 1.0500 & 0.050 & $21 / 16$ & 4600 & 33380 & 34800 & $4-\# 3$ \\
\hline & M13-12-.5B & 0.050 & 1.0500 & 0.050 & $25 / 16$ & 4720 & 3710 & 38190 & $4-\# 3$ \\
\hline & $\begin{array}{l}\text { M13-12-.5C } \\
\text { Avg. }\end{array}$ & 0.050 & 1.0500 & 0.050 & $23 / 16$ & 4530 & 38890 & $\begin{array}{l}40860 \\
37950\end{array}$ & $4 \cdot \# 3$ \\
\hline & $M 21-12-.5 A$ & 0.075 & 0.4030 & 0.200 & $21 / 4$ & 4720 & 42560 & 43800 & $4-\# 3$ \\
\hline & $\mathrm{M} 21-12-.5 \mathrm{~B}$ & 0.075 & 0.4030 & 0.200 & $23 / 16$ & 4530 & 45180 & 47470 & $4-\$ 3$ \\
\hline & $\begin{array}{l}\text { M21-12-.5C } \\
\text { Avg. }\end{array}$ & 0.075 & 0.4030 & 0.200 & 2 & 4600 & 45140 & $\begin{array}{l}47060 \\
46110\end{array}$ & $4-\# 3$ \\
\hline & M22-12-.5A & 0.075 & 0.8060 & 0.100 & $21 / 8$ & 4720 & 41730 & 42950 & $4 \cdot \# 3$ \\
\hline & $M 22-12-.5 B$ & 0.075 & 0.8060 & 0.100 & $23 / 16$ & 4530 & 40920 & 42990 & $4-\# 3$ \\
\hline & $\begin{array}{l}\text { M22-12-.5C } \\
\text { Avg. }\end{array}$ & 0.075 & 0.8060 & 0.100 & 2 & 4600 & 37920 & $\begin{array}{l}39530 \\
41823\end{array}$ & $4-\# 3$ \\
\hline & M23-12-.5A & 0.075 & 1.6125 & 0.050 & $21 / 16$ & 4720 & 36560 & 37630 & $4-\# 3$ \\
\hline & M23-12-.5B & 0.075 & 1.6125 & 0.050 & $21 / 16$ & 4530 & 36840 & 38700 & $4-\# 3$ \\
\hline & $M 23-12-.5 C$ & 0.075 & 1.6125 & 0.050 & $21 / 16$ & 4600 & 36230 & 37770 & $4-\# 3$ \\
\hline & Avg. & & & & & & & 38033 & \\
\hline & $M 31-12-.5 A$ & 0.100 & 0.5500 & 0.200 & 2 & 4530 & 40840 & 42910 & $4-\# 3$ \\
\hline & M31-12-.5B & 0.100 & 0.5500 & 0.200 & $115 / 16$ & 4600 & 44180 & 46060 & $4-\# 3$ \\
\hline & $\begin{array}{l}\text { M31-12-.5C } \\
\text { Avg. }\end{array}$ & 0.100 & 0.5500 & 0.200 & $21 / 16$ & 4720 & 45830 & $\begin{array}{l}47170 \\
45380\end{array}$ & $4-\# 3$ \\
\hline & M32-12-.5A & 0.100 & 1.1000 & 0.100 & 2 & 4530 & 34980 & 36750 & $4 \cdot \# 3$ \\
\hline & M32-12-.5B & 0.100 & 1.1000 & 0.100 & $21 / 8$ & 4600 & 39710 & 41400 & $4-\# 3$ \\
\hline & $\begin{array}{l}\text { M32-12-.5C } \\
\text { Avg. }\end{array}$ & 0.100 & 1.1000 & 0.100 & $21 / 8$ & 4720 & 44740 & $\begin{array}{l}46050 \\
41400\end{array}$ & $4-\# 3$ \\
\hline & M33-12-.5A & 0.100 & 2.2000 & 0.050 & $115 / 16$ & 4530 & 34590 & 36340 & $4 \cdot \# 3$ \\
\hline & M33-12-.5B & 0.100 & 2.2000 & 0.050 & 2 & 4600 & 31550 & 32890 & $4-\# 3$ \\
\hline
\end{tabular}


Appendix B: Beam - end Tests ( Cont'd)

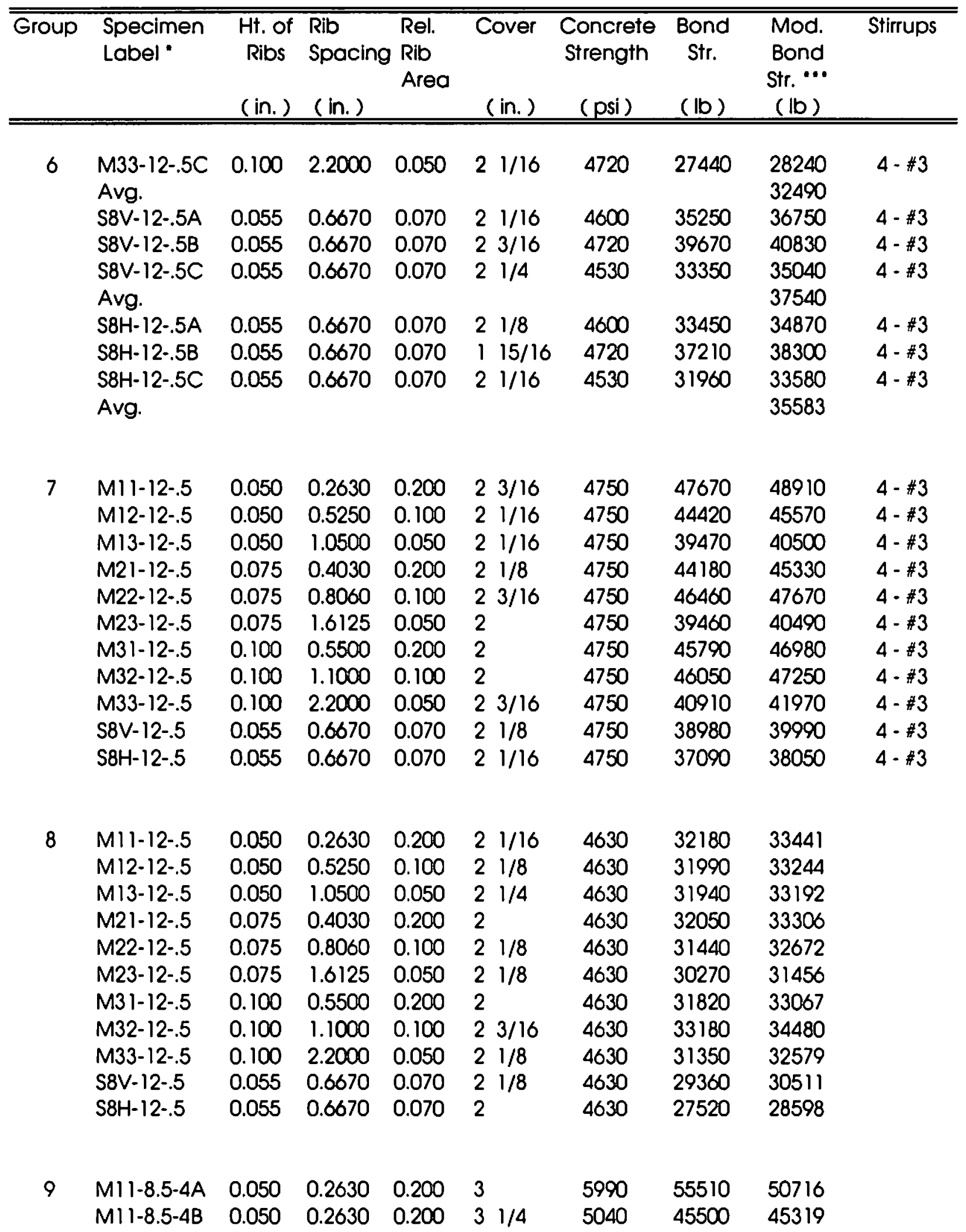


Appendix B: Beam - end Tests ( Cont'd)

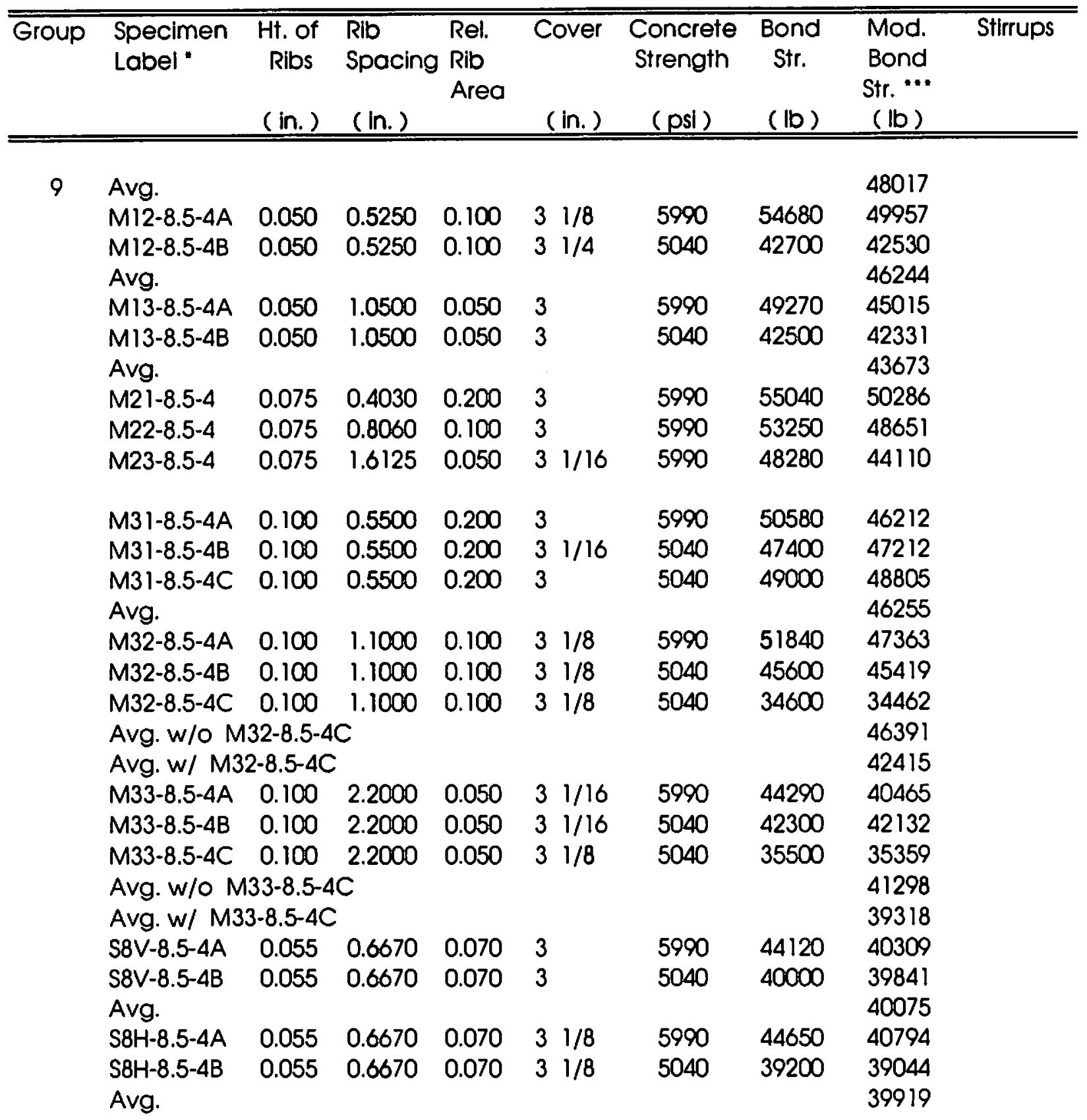

- Specimen Label

1. Machined Bars (MHX-B-LR) 2. S-Pattern $\# 8$ Bars ( $S 8 O-B-L R$ )

$H=$ Rib height designation : $1=$ Low, 0.05 in. : $2=$ Medium, 0.075 in. : $3=$ High, 0.10 in.

$X=$ Rib spacing designation : $1=$ Small : $2=$ Medium : $3=$ Large

$\mathrm{O}=$ Orientation of longitudinal $\mathrm{ib}: \mathrm{V}=$ Vertical $; \mathrm{H}=$ Horizontal 
Appendix B: Beam - end Tests ( Cont'd)

$B=$ Bonded length , in .

$L=$ Lead length, in.

$R=$ Replication mark : A , B , C

" Specimen without side stirnps

*. Modified Bond Strength = Bond Strength $\left(5000 / \mathrm{f}^{\prime} \mathrm{C}\right)^{1 / 2}$ 